\title{
Effects of water accommodated fractions of crude oils and diesel on a suite of biomarkers in Atlantic cod (Gadus morhua)
}

\author{
T.F. Holth ${ }^{a, *}$, D.P. Eidsvolla , E. Farmen ${ }^{b}$, M.B. Sanders ${ }^{c}$, C. Martínez-Gómez ${ }^{d}$, H. Budzinskie, \\ T. Burgeot ${ }^{\dagger}$, L. Guilhermino ${ }^{g}$, K. Hylland ${ }^{a}$
}

\footnotetext{
a Department of Biosciences, University of Oslo, PO Box 1066 Blindern, N-0316 Oslo, Norway

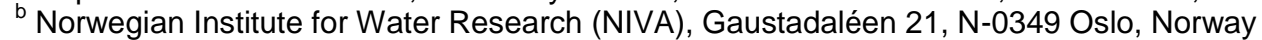

${ }^{c}$ CEFAS Weymouth Laboratory, The Nothe, Barrack Road, Weymouth, Dorset Dt4 8UB, England

d Instituto Español de Oceanografía, San Pedro del Pinatar, 30740 Varadero 1, Spain

e ISM, Université Bordeaux 1, 351 crs de la Libération, 33405 Talence, France

' IFREMER, Unit of research in Biogeochemistry and Ecotoxicology, Rue de I'lle d'Yeu, BP 21105, 44311 Nantes, France

${ }^{g}$ CIIMAR - Interdisciplinary Centre of Marine and Environmental Research, Laboratory of Ecotoxicology and Ecology \& ICBAS-Institute of Biomedical Sciences of Abel Salazar, Department of Population Studies, Laboratory of Ecotoxicology, University of Porto, Rua dos Bragas 289, 4050-123 Porto, Portugal
}

*: Corresponding author : T.F. Holth, tel.: +4722855600 ; fax: +4722854726 ; email address : t.f.holth@ibv.uio.no

\begin{abstract}
:
The aim of this study was to characterise concentration- and time-dependent responses in juvenile Atlantic cod (Gadus morhua) following exposure for one and three weeks to the water-soluble fraction (WAF) of three weathered oils: Arabian Light crude oil (ALC), North Sea crude oil (NSC) and shipdiesel. The sum of polycyclic aromatic hydrocarbons (PAH) in water was highest after one week of exposure and within environmentally relevant concentrations. PAH metabolites in bile confirmed exposure to and uptake of PAHs. Hepatic cytochrome P450 1A (CYP1A) gene expression (here and later the phrase gene expression is used synonymously to gene transcription, although it is acknowledged that gene expression is also regulated by, e.g., translation and protein stability) increased dramatically following exposure to all three oil types (fold-change up to 165), and there was a time lag between gene and protein expression. Hepatic CYP1A protein concentration and ethoxyresorufin-O-deethylase (EROD) activity were however more variable among individuals and treatments than gene expression. Hepatic and gill EROD increased in fish exposed to WAF from the two crude oils, but not in fish exposed to WAF from diesel. Exposure to diesel appeared to induce oxidative stress to a larger extent than exposure to crude oils. Other biomarkers (glutathione Stransferases, acetylcholine esterase, vitellogenin) did not appear to respond to the exposure and hence did not discriminate among oils. Biomarker responses in cod after exposure to weathered crude oils and diesel suggested the CYP1A system and oxidative stress markers to have the highest potential for discriminating among different oil types and to monitor the environmental consequences of spills.
\end{abstract}

Keywords : Atlantic cod ; Biomarkers ; Weathering ; crude oil ; ship-diesel ; water accommodated fraction ; time-course 


\section{Introduction}

A range of oils with different characteristics is transported in European waters, all of which may be released to the environment as spills. Since the properties of the oils differ, it is important to understand how they affect marine organisms. A fingerprint of different sublethal responses in marine organisms for individual oils can be used to monitor the immediate effects of a spill and identify the oil causing the effects. Discharges of crude and refined oils to sea have the potential for long-term impacts on populations of marine organisms (e.g. Jewett et al., 2002; Monson et al., 2011). Polycyclic aromatic hydrocarbons (PAHs), metals, alkylphenols and naphthenic acids are some of the groups of compounds present in most oil types known to induce adverse effects on marine organisms and populations (e.g. Kavanagh et al., 2012; Meier et al., 2007; Myers et al., 2003; Vieira et al., 2009). Although the effects of accidental oil spills on marine ecosystems have been assessed for decades, the number of established biological effect methods (biomarkers) and knowledge on their sensitivity and time course development to different oil types is still limited (Martínez-Gómez et al., 2010). Following some of the largest accidental oil tanker spills in European waters ("Haven", "Braer", "Sea Empress", "Erika" and "Prestige"), the use of biomarkers included assessment of PAH metabolite formation, genotoxicity, biomarker gene expression (here and later the phrase gene expression is used synonymously to gene transcription, although it is acknowledged that gene expression is also regulated by, e.g., translation and protein stability), lysosomal membrane integrity, cytochrome P450 1A (CYP1A) protein quantity and 
ethoxyresorufin-O-deethylase (EROD) activity, antioxidant enzyme activities as well as histopathology in a variety of fish species (Amat et al., 2006; Budzinski et al., 2004; Claireaux et al., 2004; Harvey et al., 1999; Kirby et al., 1999; Marigómez et al., 2006; Martínez-Gómez et al., 2009; Pietrapiana et al., 2002; Raingeard et al., 2009; Stagg et al., 2000; Viarengo et al., 2007). These studies have shown that biomarkers are valuable tools to quantify the severity of pollution impacts on organisms and populations, but also that there are challenges in interpreting biomarker responses. For example, the potential differences in biomarker responses to oils from different geographical regions are not well known, although such knowledge could assist in selecting the optimal biomarkers to be used in post-spill monitoring (Martínez-Gómez et al., 2010).

The intensity and specificity of biological responses may differ among oil types due to differences in oil composition. Even within a defined geographical region such as the North Sea, oils and their water-accommodated fractions (WAFs) may differ substantially in their composition of most toxic substances due to natural causes (e.g. PAHs, Utvik, 1999). Weathering processes may further modify oil composition and toxicity following discharge into the environment. For example, photoenhanced toxicity of crude and bunker oil has been observed for Pacific herring (Clupea pallasi) development (Barron et al., 2003; Incardona et al., 2012). The speed and efficacy of such degradation processes may depend on oil type, but also on intensity of irradiation, mechanical breakdown and dispersion (waves, wind, gravel), ambient temperature and rate of biotransformation by microorganisms (Sauer et al., 1998). Weathering does however not always decrease oil toxicity; weathered oils generally have altered ratios of higher to lower molecular weight PAHs since the lighter PAHs are more liable to evaporate or be used as energy source by microorganisms (Neff et 
al., 2000; Wang and Fingas, 1995). Therefore, portions of an oil spill may remain bioactive for prolonged periods of time. Other common confounding factors forcing a complex interpretation of effects may be biological and ecological differences among sentinel species; differences in genetic expression, enzymatic activities and levels of other biomarkers in distinct tissues; seasonal differences; poorly known time-scale of biomarker responses and/or adaptation and recovery processes of the selected species; background/natural contamination as well as climatic conditions (e.g. Claireaux et al., 2004; Lee and Anderson, 2005; Stagg et al., 2000; Viarengo et al., 2007).

Some PAH compounds are known to affect well-characterised biotransformation systems in fish, such as CYP1A. Dioxin-like PAHs may activate the aryl hydrocarbon receptor (AhR) pathway, causing an increase in CYP1A mRNA and protein (see e.g. Goksøyr and Förlin, 1992). Furthermore, ligands of the AhR may also induce CYP1A enzymatic activity, generally measured as EROD activity (Whyte et al., 2000). In addition to indicating the presence of dioxin-like substances, induction of CYP1A activity may increase bioactivation of some PAHs causing embryotoxicity and genotoxicity (Myers et al., 2003; Hodson et al., 2007). Aneugenic and/or clastogenic DNA damage may also result in the formation of micronuclei (Jaylet et al., 1986). Quantification of micronuclei has been successfully used for decades as a biomarker for exposure to genotoxic compounds in both marine and freshwater species (Bolognesi and Hayashi, 2011).

Several known (and unknown) substances in oil WAFs may affect the endocrine system of fish (Thomas et al., 2004b; Thomas et al., 2009). Some PAHs, alkylphenols or their metabolites have been shown to have estrogenic activity (Martínez-Gómez et al., 2013), to induce vitellogenin protein synthesis in male fish (Sherry et al., 1999), and to delay gonadal development (Holth et al., 2010; Meier et 
al., 2007). PAHs and redox-active trace metals are also known to cause oxidative stress in tissues, which may lead to macromolecule inactivation and breakdown (Almeida et al., 2012; Van Der Oost et al., 2003). Oxidative stress may be monitored using several different techniques, of which the most common is monitoring of lipid peroxidation levels (thiobarbituric acid reactive substances; TBARS) (Hermes-Lima et al., 1995), and measuring the activities of antioxidant enzymes, e.g. glutathione $S$ transferases (GST; Van Der Oost et al., 2003). Furthermore, WAFs from oil may contain compounds that inhibit acetylcholine esterase (AChE) (Holth and Tollefsen, 2012), an enzyme associated with the hydrolysis of acetylcholine in the synaptic cleft. Reduced AChE activity may lead to acetylcholine accumulation, continuous nerve stimulation, ataxia and death, and this activity has been extensively used as a biomarker for organophosphorous insecticide exposure in both marine fish and invertebrates (Costa, 2006; Fulton and Key, 2001), but has also been shown to be affected by other environmental contaminants such as some PAHs and metals (Roche et al., 2002; Vieira et al., 2009).

In the current study, we aimed to assess how WAFs from three weathered oil types would affect a suite of biomarkers in Atlantic cod (Gadus morhua). Juvenile Atlantic cod were exposed for one and three weeks to WAFs from three commonly transported oil types in Europe: Arabian Light crude oil, North Sea crude oil and shipdiesel. Tissues were sampled and analysed for PAH metabolites in bile, CYP1A gene expression and protein quantity in liver, EROD activity in liver and gills, lipid peroxidation levels (TBARS) and GST activity in gills, AChE activity in muscle, vitellogenin concentration in plasma and the frequency of micronuclei in erythrocytes. 


\section{Materials \& Methods}

\subsection{Chemicals and weathering of oils}

The oils, Arabian Light crude oil (ALC), North Sea crude oil (NSC) and marine gas oil (ship-diesel), were selected based on their differences in geographic origin and composition of main groups of hydrocarbons (figure 1). Details of oil composition were presented in Radović et al. (2012), in which the diesel used in this work was diesel B. Artificial weathering was performed according to the method described by Smith et al. (2005): the oils were mixed with seawater $\left(1: 1 \mathrm{v} \mathrm{v}^{-1}\right)$ and stirred using a magnetic stirrer in a fume hood for 24 hours at room temperature. Following a resting phase, water and oil was separated. The weathered oils were mixed with clean gravel (4-5 $\mathrm{mm}$ diameter) at concentrations of 2 and 6 grams oil $\mathrm{kg}^{-1}$ gravel (dichloromethane was used as solvent). Treated gravel was air dried in a fume hood for 24 hours at room temperature, frozen at $-20^{\circ} \mathrm{C}$ and stored until use. Gravel used for the control group was treated similarly, including solvent addition, evaporation and freezing. Unless otherwise mentioned, all chemicals were purchased from Sigma Aldrich (St. Louis, Oregon, USA).

\subsection{Fish and experimental setup}

Juvenile Atlantic cod were exposed in 4 replicates to two doses of WAFs from three different oils in addition to a seawater control. Cod were purchased from Profunda AS (Barstadvik, Norway). Cod length and weight were $17.8 \pm 0.2 \mathrm{~cm}$ and $47.6 \pm 1.3 \mathrm{~g}$ (average \pm SE). Following transportation, cod juveniles were acclimated to system water for at least two weeks before introduction into the exposure system. Cod juveniles were fed with 0.5 grams of boiled commercial Faeroese shrimps per fish per day throughout the study, except for three consecutive days before the samplings to 
promote concentration of bile. System water intake was at 34 meters depth from the outer Oslofjord, with an average temperature of $10.2^{\circ} \mathrm{C}$ and salinity of $32.0 \%$. A total of 56 fish were distributed into 28 tanks (i.e. two fish per tank) giving one control group and six exposed groups, each of 4 replicate tanks (figure 2). Tank volumes were $20 \mathrm{~L}$ and the nominal flow rate was $50 \mathrm{~mL} \mathrm{~min}^{-1} \operatorname{tank}^{-1}$, equivalent to 3.6 water volume exchanges per day and a fish loading rate of $1.3 \mathrm{~g} \mathrm{~L}^{-1} \mathrm{day}^{-1}$. Oxygen concentration was monitored throughout the exposure period $\left(>5 \mathrm{mg} \mathrm{L}^{-1}\right)$. Tanks were covered with lids and separated by blinds in the interspaces. Weathered oil WAFs were produced by allowing seawater to percolate through columns containing oilcovered gravel (Carls et al., 1999). Clean and soiled gravel (650 g) were introduced into their respective columns $(\mathrm{d}=75 \mathrm{~mm}, \mathrm{~h}=350 \mathrm{~mm})$ and flow was applied 24 hours before the experiment started to reduce eventual initial elevated concentrations of volatile organic compounds (VOC) or oil droplets. All tubings were made of Teflon ${ }^{\mathrm{TM}}$ and tanks were of a whole glass construction with no silicone seams. The experiment was run continuously for 3 weeks. There was no mortality during the experiment period.

\subsection{Tissue sampling}

One cod was sampled from each tank one and three weeks after the start of exposures. In addition, eight fish were sampled prior to the start of the exposure to indicate the background levels of the biomarkers being measured (pre-exposure control samples). All fish were anaesthetised by brief immersion in MS-222 (Sigma-Aldrich AS; $0.5 \mathrm{~g}$

$\mathrm{L}^{-1}$ ) and sacrificed by a blow to the head. Length and weight were recorded and blood was collected from the caudal vein using a heparinised syringe. A drop of blood was immediately prepared for micronucleus assessment. The remainder of the blood sample was centrifuged (2,000 $\mathrm{x} g$ for 5 minutes) to separate blood cells and plasma, 
which were frozen in separate tubes in liquid nitrogen. Two gill arches were excised: one gill arch was immediately assessed for EROD activity, the other was snap frozen in liquid nitrogen. The cod were dissected, the gall bladder excised and frozen at $20^{\circ} \mathrm{C}$. The liver was weighed, split into replicates and frozen on liquid nitrogen. A muscle sample was excised from the area below the first dorsal fin and immediately snap-frozen on liquid nitrogen. The gonads were not sufficiently developed for visual sex determination.

\subsection{Monitoring of PAHs and VOCs in water and PAH metabolites in cod bile}

Water samples $(100 \mathrm{~mL})$ were collected in amber glass flasks from each tank one and three weeks after the start of exposures, frozen at $-20^{\circ} \mathrm{C}$ and stored until analysis (approx. 1 year). Before use, the flasks were washed 3 times in acetone and autoclaved. Teflon caps were used.

Water samples were analysed for PAHs according to a method adapted from the one described in De Perre et al. (2014). Briefly, SPME (solid phase micro-extraction) analyses of $9 \mathrm{~mL}$ water samples (in $10 \mathrm{~mL}$ vials) were performed with commercially available PDMS (polydimethylsiloxane $100 \mu \mathrm{m}$ ) fibers from Supelco (Bellefonte, USA). After the immersion of the fiber in the water sample $\left(60\right.$ minutes; $30^{\circ} \mathrm{C} ; 250$ $\mathrm{rpm})$, it was immediately desorbed into the GC-MS injection port $\left(5 \mathrm{~min} ; 270^{\circ} \mathrm{C}\right)$.

Water samples were analysed for VOC by headspace SPME analyses. Ten $\mathrm{mL}$ of water was put in $20 \mathrm{~mL}$ vials and extraction performed in the headspace part of the vial with commercially available PDMS $\left(30 \mathrm{~min} ; 50^{\circ} \mathrm{C} ; 250 \mathrm{rpm}\right)$. The PDMS fiber was immediately desorbed into the GC-MS injection port $\left(10 \mathrm{~min} ; 220^{\circ} \mathrm{C}\right.$; pulsed splitless). The GC flow was $1.3 \mathrm{~mL} \min ^{-1}$ (helium 6.0 constant flow) and the 
temperature program was as follows: start at $20^{\circ} \mathrm{C}(10 \mathrm{~min})$; increase to $200^{\circ} \mathrm{C}(5$ min) at $10^{\circ} \mathrm{C} \min ^{-1}$ and finally to $300^{\circ} \mathrm{C}(9 \min )$ at $25^{\circ} \mathrm{C} \mathrm{min}^{-1}$.

Analyses of PAHs and VOCs in water were performed in automated mode using a Gerstel MPS2XL (RIC, Belgium) and the GC was an Agilent 7890A model (Agilent Technologies, France) equipped with a 5975C mass selective detector, operated with an energy of ionization of $70 \mathrm{eV}$ (electronic impact). The column used was an HP5MS-UI ((5\%-phenyl)-methylpolysiloxane; $30 \mathrm{~m} \times 0.25 \mathrm{~mm}$ i.d.; $0.25 \mu \mathrm{m}$ film; Agilent Technologies, France).

For the determination of PAHs and VOCs, the mass spectrometer was operated in the Selected Ion Monitoring (SIM) acquisition mode and the molecular ions were sought (PAHs: table S1; VOCs: table S2). Quantification was performed using internal perdeuterated standards (for PAHs at least one per aromatic class) added prior to SPME extraction in the sample directly by gravimetry (few $\mu \mathrm{L}$ of ethanolic solution; table S1 and S2 for PAHs and VOCs, respectively). The response factors of the different compounds were measured by injecting a solution of unlabelled standards mixed with deuterated compounds used as surrogate standards (determined at different levels of concentrations).

The procedural limits of detection (LODs) and quantification (LOQs) were determined by analysis of spiked milli-Q (MQ) and natural mineral water at various concentrations, for a signal to noise ratio of three for LODs and ten for LOQs. Limits of detection (LODs) were comprised between $0.1-0.5 \mathrm{ng} \mathrm{L}^{-1}$ for PAHs and $0.5-2$ $n \mathrm{~L} \mathrm{~L}^{-1}$ for VOCs. Limits of quantification (LOQs) were comprised between $0.3-1.5$ $n g \mathrm{~L}^{-1}$ for PAHs and $1.5-6 \mathrm{ng} \mathrm{L}^{-1}$ for VOCs. Analytical variability was determined on spiked MQ and mineral water samples $(\mathrm{n}=5)$ and was found to be below $10 \%$ for all PAHs and below $20 \%$ for all VOCs. 
Bile samples were analysed for PAH metabolites, according to a method adapted from Mazéas and Budzinski (2005), Wessel et al. (2013) and Dévier et al. (2013). Briefly, metabolites were extracted after deconjugation by solid phase extraction (SPE). Purified extracts were analysed by UPLC/MSMS (Wessel et al. 2013, Le Dû-Lacoste, 2008). The reported sums of hydroxylated non-alkylated PAHs included $1+2 \mathrm{OH}-$ naphthalenes $\quad(\Sigma-\mathrm{OH}-n a p h t h a l e n e s), \quad 1+2+3+4+9 \quad \mathrm{OH}-$ phenanthrenes $\quad(\Sigma-\mathrm{OH}-$ phenanthrenes) and $3+9$ OH-benzo[a]pyrenes $(\Sigma-\mathrm{OH}-\mathrm{BaP})$. Quantification was performed using internal standards (deuterated hydroxy-pyrene, 1-OHPyrd9) added prior to SPE extraction and the response factors were measured by injecting a solution of unlabelled standards mixed with deuterated compounds used as surrogate standards (table S3). LODs and LOQs were 0.3 and $1 \mathrm{ng} \mathrm{g}^{-1}$, respectively. Analytical variability was determined on spiked MQ, mineral water and bile samples $(\mathrm{n}=5)$ and was below $20 \%$ for all the compounds. For details on quality assurance and control procedures see supplementary information 1.

\subsection{Hepatic RNA isolation, cDNA synthesis and RT-qPCR}

Livers were homogenized at 5,500 rpm for $3 \times 10$ seconds in tubes containing zirconium beads and $96 \%$ ethanol using a Precellys homogenizer (Bertin Technologies, Paris, France). Following centrifugation for 2 minutes at $10,000 \mathrm{x} g$, the resulting pellet was homogenized in $400 \mu \mathrm{L}$ lysis buffer (E.Z.N.A. Total RNA Kit I, Omega Bio-Tek, Norcross, GA). Following another centrifugation (2 min; 10,000 x $g)$, nucleic acids were precipitated from supernatant by addition of ethanol $\left(1: 1 \mathrm{v} \mathrm{v}^{-1}\right)$. RNA was purified on filter columns using the E.Z.N.A. Total RNA Kit I following the manufacturers instructions. RNA quantity and quality were determined using a nanodrop spectrophotometer (Nanodrop Products, Wilmington, DE) and a 2100 bioanalyzer instrument (Agilent Technologies Inc., Santa Clara, CA), respectively. 
Synthesis of cDNA (RNA input $1 \mu \mathrm{g}$ ) was performed using the qScript cDNA supermix (Quanta BioSciences, Gaithersburg, MD). A standard curve (200, 40, 8, 1.6 ng total RNA) was included giving a 91\% reaction efficiency. Primer sequences for CYP1A used for RT-qPCR (PerfeCta SYBR Green Fastmix with low ROX, Quanta BioSciences) were CCAACTTACCTCTGCTGGAAGC (forward) and GGTGAACGGCAGGAAGGA (reverse) (Rees et al., 2003). Annealing temperature was $60^{\circ} \mathrm{C}$.

\subsection{Hepatic CYP1A protein quantity and EROD activity}

The hepatic CYP1A protein content was analysed by a semi-quantitative enzymelinked immunosorbent assay (ELISA) as described in Holth et al. (2008), with the following modifications. Livers were homogenised in potassium phosphate buffer ( 5 $\mathrm{mL} \mathrm{g}^{-1}$ tissue; $0.1 \mathrm{M} \mathrm{pH} \mathrm{7.8;0.15M} \mathrm{KCl;} 1 \mathrm{mM}$ DTT; $5 \%$ glycerol) using glassware and a teflon pistil with tight fit (Potter-Elvehjem). Homogenates were centrifuged at $12,000 \times \mathrm{g}$ for 20 minutes at $4^{\circ} \mathrm{C}$ to remove cell debris. The supernatant was centrifuged at $50,000 \times \mathrm{g}$ for 2 hours at $4{ }^{\circ} \mathrm{C}$. The microsomal pellets were resuspended in potassium phosphate buffer $(0.1 \mathrm{M} \mathrm{pH} 7.8 ; 0.15 \mathrm{M} \mathrm{KCl} ; 1 \mathrm{mM}$ EDTA; $20 \%$ glycerol) and frozen at $-80^{\circ} \mathrm{C}$ before quantification of CYP1A protein (LOQ 4.5 mOD $\mu \mathrm{g}^{-1}$ protein). The EROD activity was measured in $\mathrm{S} 9$ fraction of liver homogenates as described in Burgeot et al. (1996) using the method of Burke and Mayer (1974), modified for plate readers by Galgani and Bocquene (1991).

\subsection{EROD activity in gills}

The assay was performed as described in Jönsson et al. (2002), with the following modifications. One gill arch was excised and placed in $0.5 \mathrm{~mL}$ ice-cold HEPEScortland buffer pH $7.7(0.13 \mathrm{M} \mathrm{NaCl}, 6.0 \mathrm{mM}$ HEPES, $5.6 \mathrm{mM}$ glucose, $5.1 \mathrm{mM} \mathrm{KCl}$, 
$2.4 \mathrm{mM} \mathrm{NaH}_{2} \mathrm{PO}_{4}, 1.6 \mathrm{mM} \mathrm{CaCl}_{2}, 0.9 \mathrm{mM} \mathrm{MgSO}_{4}$ ) in a 24-well microtiter plate. The assay was started by replacing HEPES-cortland buffer with $0.5 \mathrm{~mL}$ room tempered EROD-buffer (HEPES-cortland buffer containing $1 \mu \mathrm{M}$ dicumarol and $20 \mu \mathrm{M}$ resorufin ether). After 2 minutes, the EROD-buffer was replaced with $0.5 \mathrm{~mL}$ fresh room tempered EROD-buffer. The samples were incubated in the dark for 30 minutes at room temperature. Two hundred microlitres of samples, blanks (EROD-buffer) and a resorufin standard dilution series ranging from $6-200 \mathrm{nM}$ were transferred in duplicates to a 96-well plate and fluorescence $(535 / 585 \mathrm{~nm})$ determined (Bio-Tek FL800x; LOQ $1.7 \mathrm{fmol} \mathrm{min}{ }^{-1}$ filament ${ }^{-1}$ ). The number of incubated gill filaments was counted (approximately 30 filaments per fish) and results were reported as fmol resorufin minute ${ }^{-1}$ filament $^{-1}$ (Jönsson et al., 2003).

\subsection{Glutathion S-transferase (GST) activity in gills}

Gill filaments were added $4 \mathrm{~mL}$ potassium phosphate buffer $(0.1 \mathrm{M}, \mathrm{pH} 6.5)$ and homogenized using glassware and a teflon pistil with tight fit (Potter-Elvehjem). Homogenized samples were centrifuged $\left(9,000 \times \mathrm{g}, 30\right.$ minutes, $\left.4^{\circ} \mathrm{C}\right)$ and supernatant used to determine broad spectred GST activity as described by Habig and Jakoby (1981), adapted to microtiter plates by Frasco and Guilhermino (2002). Three replicates $(100 \mu \mathrm{L})$ of blanks and samples were added to microtiter plates and reactions started by addition of $200 \mu \mathrm{L}$ potassium phosphate buffer containing $10 \mathrm{mM}$ glutathione and $10 \mathrm{mM}$ 1-chloro-2,4-dinitrobenzene. Optical density was monitored (340 nm) every 20 seconds for 5 minutes using a microtiter plate spectrophotometer (Bio-Tek PowerWave 340 ) at $25^{\circ} \mathrm{C}$. The enzymatic activity was calculated from the slope of the absorbance curve and was expressed in $\mu \mathrm{mol} \mathrm{min} \mathrm{mg}^{-1} \mathrm{mg}^{-1}$ proin (LOQ

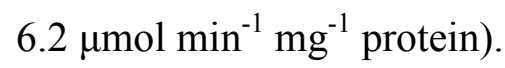




\subsection{Acetylcholinesterase (AChE) activity in muscle}

Approximately $1 \mathrm{~g}$ of muscle was added $4 \mathrm{~mL}$ potassium phosphate buffer $(0.1 \mathrm{M}, \mathrm{pH}$ 7.2) and homogenized using glassware and a teflon pistil with tight fit (PotterElvehjem). Homogenized samples were centrifuged at 5,000 $\mathrm{x} g$ for 5 minutes at $4{ }^{\circ} \mathrm{C}$ to remove cell debris. The supernatant was diluted 10 times in potassium phosphate buffer and frozen at $-80^{\circ} \mathrm{C}$ until analysis. The determination of AChE activity was performed according to the method described by Ellman et al. (1961), adjusted for use in microtiter plates (Guilhermino et al., 1996). Four replicates $(50 \mu \mathrm{L})$ of blanks and samples were added to microtiter plates and reactions started by addition of $250 \mu \mathrm{L}$ potassium phosphate buffer containing $0.5 \mathrm{mM}$ acetylthiocholine iodide, $0.33 \mathrm{mM}$ 5,5'-dithiobis-(2-nitrobenzoic acid) and $0.6 \mathrm{mM}$ sodium bicarbonate. Optical density was monitored (414 nm) every 2 minutes for 10 minutes using a microtiter plate spectrophotometer (Bio-Tek PowerWave 340) at $25^{\circ} \mathrm{C}$. Protein concentration in muscle homogenates was determined using the method of Bradford et al. (1976) as indicated in Frasco and Guilhermino (2002). The enzymatic activity was calculated using the extinction coefficient of 5-thio-2-nitrobenzoic acid (TNB) $\left(\varepsilon=1.36 \times 10^{4}\right.$ $\mathrm{mL} \mathrm{mmol}^{-1} \mathrm{~cm}^{-1}$ ) from the slope of the absorbance curve and was expressed as nmol thiocholine $\mathrm{min}^{-1} \mathrm{mg}^{-1}$ protein (LOQ $0.8 \mathrm{nmol} \mathrm{min} \mathrm{mg}^{-1}$ protein).

\subsection{Lipid hydroperoxide (LPO) concentration in gills}

Gill samples (filaments) were homogenized $\left(1: 10 \mathrm{~g} \mathrm{wt}^{-1}\right)$ in potassium phosphate buffer (0.1 M, pH 7.4) and endogenous LPO determined through measurements of thiobarbituric acid reactive species (TBARS), according to Ohkawa et al. (1979) and Bird and Draper (1984). Artificial lipid oxidation was prevented by addition of 0.2 $\mathrm{mM}$ butylhydroxytoluene (Torres et al., 2002). Gill homogenates $(0.2 \mathrm{~mL})$ were 
added $1 \mathrm{~mL} \mathrm{12 \%}$ trichloroacetic acid, $1 \mathrm{~mL} 0.73 \%$ thiobarbituric acid and $0.8 \mathrm{~mL} 60$ $\mathrm{mM}$ Tris- $\mathrm{HCl}(\mathrm{pH} 7.4)$ containing $0.1 \mathrm{mM}$ DTPA. Following incubation (60 minutes, $100^{\circ} \mathrm{C}$ ) the solution was centrifuged at $12,000 \times \mathrm{g}$ for 5 minutes and optical density determined (535 nm) using a microtiter plate spectrophotometer (Bio-Tek PowerWave 340). LPO concentrations were expressed as nmol TBARS $\mathrm{g}^{-1}$ wt (LOQ: 202 nmol TBARS g-1 wt).

\subsection{Vitellogenin protein quantity in plasma}

Plasma samples were analysed for the presence of vitellogenin (VTG), the female specific egg yolk protein, using a validated homologous ELISA method (Scott et al., 2002, 2006a, 2006b). The limit of detection was $93 \mathrm{ng} \mathrm{mL}^{-1}$, estimated from $2 \mathrm{x}$ standard deviation of 15 blank measurements.

\subsection{Micronucleus in erythrocytes}

After three weeks of exposure, a blood smear was made from one drop of heparinized blood on a microscope slide. Samples were air dried at room temperature and stored in the dark at $4^{\circ} \mathrm{C}$ until analysis. The samples were fixed $\left(3: 1 \mathrm{v} \mathrm{v}^{-1}\right.$ methanol:acetic acid) for 5 minutes, air dried and incubated for 40 minutes in 3\% giemsa stain. The samples were washed twice (tap water), air-dried and a cover slide was mounted. Quantification of micronuclei in 5,000 cells per sample was assessed using a microscope (Olympus BX41TS, Tokyo, Japan) at 400x magnification, following the scoring criteria as summarised in Baršienè et al. (2012).

\subsection{Statistical analyses}

Statistical analyses were performed using $\mathrm{JMP}{ }^{\circledR}$ version 8.0 .2 (SAS Institute Inc., Cary, NC, USA) and Microsoft Excel 2008 for Mac (Microsoft Corp., Redmond, 
WA). One-way ANOVA was performed on data from cod sampled one and three weeks after the start of exposures for analysis of effects of treatments. Furthermore, a one-way ANOVA was performed on data from each treatment group (including preexposure control) for analysis of within group temporal development. Samples for both types of analyses were treated as independent, assuming negligible effects of fish density for the latter analysis (sampled fish were terminated on each occasion). The general model assumptions (homoscedasticity and variance to mean relationships) were evaluated using Levene's test $(p<0.05)$ and residual plots, respectively. If necessary, the data was $\log ^{10}$-transformed and re-evaluated. Following significant ANOVAs a Dunnett's post-hoc test was performed (Sokal and Rohlf, 1994). When parametric tests were not applicable, non-parametric Kruskal-Wallis was used followed by a non-parametric post-hoc test (Conover, 1999). Applied transforms can be seen in table S4. If any value within a group was reported as below LOQ, the data set was not statistically tested. Furthermore, $p$ values were adjusted for multiple comparisons before non-parameteric post-hoc tests using the formula $p_{\text {adj }}=p / \mathrm{k} \mathrm{x} \mathrm{(k-}$ 1), where $\mathrm{k}=$ the number of groups for comparison. Fold-change values for each biomarker (except vitellogenin and micronucleus) were calculated as ratios between values for individuals exposed to WAF from oil or diesel and the mean of the respective control group. For statistical testing of micronucleus data, samples were assigned a categorical variable (MN present or MN absent). Data were compiled in a contingency table and a Pearson chi-square test applied (Sokal and Rohlf, 1994). Unless otherwise mentioned, quantification limits were estimated from $3 \mathrm{x}$ standard deviations of several blank measurements. 


\section{Results}

\subsection{PAH and VOC in water}

After one week, there were significantly higher concentrations of most PAHs in water in all $6 \mathrm{~g}$ oil kg${ }^{-1}$ gravel treatments compared to the control (table 1). WAFs of 2 g oil $\mathrm{kg}^{-1}$ gravel were in most cases not significantly different from control (table 1). There were no significant differences for VOC in water among treatments (table 1). WAF of $6 \mathrm{~g}$ diesel $\mathrm{kg}^{-1}$ gravel contained the highest concentrations of $\Sigma \mathrm{PAH}$ and alkylated naphthalenes: approximately twice the concentrations produced by $6 \mathrm{~g}$ NSC $\mathrm{kg}^{-1}$ gravel and two to three times the concentrations produced by $6 \mathrm{~g} \mathrm{ALC} \mathrm{kg}^{-1}$ gravel (table 1). The concentrations of alkylated phenanthrenes were similar between the respective doses of all WAFs, but concentrations of dibenzothiophene and its alkylated derivatives were 6 to 50 times higher in the WAF of the ALC treatments than in the WAFs of the NSC and diesel treatments (table 1).

Three weeks after the start of exposures, $\Sigma \mathrm{PAH}$ concentrations in all treatments were close to background and only $\Sigma \mathrm{PAH}$ concentrations in WAF of $6 \mathrm{~g} \mathrm{NSC} \mathrm{kg}^{-1}$ gravel were significantly higher than the control (table 1). VOC concentrations in

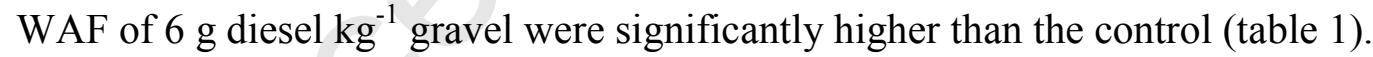

Detailed data on PAHs on VOCs in water can be found in tables S5 and S6, respectively.

\subsection{PAH metabolites in bile}

Exposure to crude oil or ship-diesel resulted in significantly increased concentrations of PAH bile metabolites for the high concentrations of all three oils after one week ( $\mathrm{p}=0.01$, Dunnetts test for sum OH-PAH; table 2), but not for the low concentration or after three weeks exposure. Bile metabolite concentrations decreased 
significantly for all treatments from 1 to 3 weeks (GLM; $p=0.0003$ for sum $\mathrm{OH}$ PAH; table 2). Ratios between low molecular weight ( $\leq 4$-ring $\mathrm{OH}-\mathrm{PAH})$ and high molecular weight (5-ring OH-PAH) were higher in fish exposed to diesel than in fish exposed to crude oils ( $\mathrm{p}=0.005$, Kruskal Wallis for ratio data, table 3 ).

\subsection{Hepatic CYP1A gene expression and protein}

CYP1A gene expression was significantly increased in cod from all groups after one week of exposure when compared to the control group (table 4; figure $3 \mathrm{~A}$ ) and to the pre-exposure control group (table 4). Three weeks after the start of exposures, cod from all treatment groups except $2 \mathrm{~g}$ diesel $\mathrm{kg}^{-1}$ gravel still had increased hepatic CYP1A gene expression compared to the control group (table 5; figure 3B) and the pre-exposure control group (table 5).

CYP1A protein in liver was significantly increased in cod exposed for three

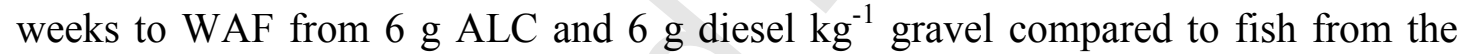
control group (table 5; figure 3B), but there were no significant differences compared to the pre-exposure control group (table 5). There were no significant differences in hepatic CYP1A protein after one week of exposure (table 4; figure 3A).

\subsection{EROD activity in liver and gills}

Hepatic EROD activity was significantly increased after one week in cod exposed to WAF from $2 \mathrm{~g} \mathrm{NSC} \mathrm{kg}{ }^{-1}$ gravel and $6 \mathrm{~g} \mathrm{ALC} \mathrm{kg}^{-1}$ gravel compared to the control group (table 4; figure 3A). Three weeks after the start of exposures, hepatic EROD activity was still significantly increased in cod exposed to WAF from $6 \mathrm{~g}$ ALC $\mathrm{kg}^{-1}$ gravel, and also in cod exposed to WAF from $6 \mathrm{~g} \mathrm{NSC} \mathrm{kg}^{-1}$ gravel (table 5; figure 3B). Compared to cod from the pre-exposure control group, hepatic EROD activity was increased in cod exposed to WAF from 2 and $6 \mathrm{~g} \mathrm{NSC} \mathrm{kg}^{-1}$ gravel after one and 
three weeks, respectively, as well as in cod exposed for three weeks to WAF from $6 \mathrm{~g}$ $\mathrm{ALC} \mathrm{kg}^{-1}$ gravel (table 4 and 5).

Gill EROD activity was significantly induced after three weeks in cod exposed to WAF from 2 and $6 \mathrm{~g} \mathrm{NSC} \mathrm{kg}^{-1}$ gravel as well as 2 and $6 \mathrm{~g} \mathrm{ALC} \mathrm{kg}^{-1}$ gravel compared to cod from the control group, but activity related to dose only in the ALC treatment (table 5; figure 3B). Cod exposed to ALC and NSC WAF had significantly induced activities compared to cod from the pre-exposure control group (table 5). After one week of exposure, gill EROD activity in cod from the control group, ALC and NSC groups was significantly increased compared to cod from the pre-exposure control group (table 4), and a dose related trend was apparent in all treatments $(\mathrm{F}=2.5$, $p<0.06)$.

\subsection{Glutathione $S$-transferase (GST) activity in gills}

There were no significant differences in GST activity in gills in cod among groups after one and three weeks of exposure (table 4 and 5; figure 4). Compared to cod from the pre-exposure control group, there was a significant reduction in gill GST activity after three weeks in cod exposed to WAF from $6 \mathrm{~g}$ diesel $\mathrm{kg}^{-1}$ gravel (table 5).

\subsection{Lipid peroxidation (TBARS) in gills}

After three weeks the level of gill TBARS was significantly increased in cod exposed to WAF from $2 \mathrm{~g}$ diesel $\mathrm{kg}^{-1}$ gravel (table 5; figure 4B). One week after the start of exposure there were no significant differences among groups (table 4; figure $4 \mathrm{~A})$. 


\subsection{Acetylcholinesterase (AChE) activity in muscle}

Compared to the pre-exposure control group, AChE activity in muscle was significantly reduced after one week in cod from the control group and in cod exposed to WAF from ALC oil and WAF from $6 \mathrm{~g} \mathrm{NSC} \mathrm{kg}^{-1}$ gravel (table 4). Similarly, after three weeks the AChE activity in muscle was significantly reduced in cod from the control group and in cod exposed to WAF from ALC oil (table 5). There were no significant differences in muscle AChE activity among exposure groups within the different timepoints.

\subsection{Vitellogenin in plasma}

Due to a large fraction of cod with plasma vitellogenin concentrations below the limit of detection (LOD; $93 \mathrm{ng} \mathrm{vtg} \mathrm{mL}^{-1}$ ), no statistical analysis was performed (table S7). In cod from the pre-exposure control group, four out of eight values were below LOD and the remaining four were close to LOD $\left(<107 \mathrm{ng} \operatorname{vtg} \mathrm{mL}^{-1}\right)$. More fish had vitellogenin concentrations in plasma above LOD after three weeks of exposure than after one week of exposure. Most of the fish exposed to the highest oil concentrations for three weeks had vitellogenin concentrations in plasma above LOD (table S7).

\subsection{Micronucleus in erythrocytes}

There were no significant differences between treatments in the frequency of fish with micronuclei present/absent in erythrocytes (table S8).

\section{Discussion}

Atlantic cod was exposed to water-accommodated fractions (WAFs) from three weathered oils (ALC, NSC, ship-diesel) in a continuous flow-through system for three weeks. The selected concentrations of oil simulated a light contamination: a 
discolouring of the gravel was only observed when applying $6 \mathrm{~g} \mathrm{oil} \mathrm{kg}^{-1}$ gravel. The concentrations of $\Sigma \mathrm{PAH}$ in WAFs one week after the start of the experiment were in the environmentally relevant $\mathrm{ng}^{-1}$ range $(12.5-184.9)$ : depending on weather conditions and the distance from an oil spill site, hydrocarbon concentrations in seawater in areas impacted by oil spills may range from $\mathrm{ng} \mathrm{L}^{-1}$ concentrations to short periods of concentrations in the $\mathrm{mg} \mathrm{L}^{-1}$ range (Elordui-Zapatarietxe et al., 2010; González et al., 2006; Reddy and Quinn, 2001; Stagg et al., 2000). $\mathrm{PAH}$ concentrations in seawater receiving oil production wastewater have been estimated to be in the lower (30-50) ng $\mathrm{L}^{-1}$ range (Harman et al., 2009), a similar concentration range as in the current experiment. For comparison, PAH reference concentrations for OSPAR region IV were suggested to be in the $\mathrm{pg} \mathrm{L}^{-1}$ range (OSPAR Commision, 2004).

There was no relationship between water concentrations of PAHs after one week and the general characterisation of oil hydrocarbons in the original oils. The oil containing the largest fraction of mono- and polyaromatic compounds (Arabian Light; $39.6 \%$ ) did not result in the highest concentrations of $\Sigma \mathrm{PAHs}$ or alkylated naphthalenes/phenanthrenes in water. There are many possible explanations for this observation, predominantly associated with properties of the exposure system and the WAF produced. We have no measurement of what came out of the columns the first week, during which there could have been a depletion of some of the components for some oils. Arabian Light contained more asphalthenes than any of the other oils. Asphalthenes could have produced a more viscous matrix, thereby reducing the leaching rate of other components of the oil. The rate of release of the smaller PAHs may be larger from lower doses than from higher doses (Nahrgang et al., 2010). Such effects may cause water PAH concentrations to differ among oil types, and not 
necessarily in correlation to parent oil hydrocarbon composition. The concentrations of dibenzothiophenes and its derivatives were higher in the ALC treatments than in the NSC and diesel treatments, in correspondence with the higher sulphur content (including PAH heterocycles) of this oil type (Radović et al., 2012). The temporal reduction in PAH concentrations in water between one and three weeks was an expected result of the columns used for generating exposure (Carls et al., 1999), and further augments the environmental relevance of the study. By using biological biomarkers, variations in water contaminant concentration are integrated over time (see e.g. Aas et al., 2000a), reducing the complexity of impact assessment.

The increased concentrations of PAH metabolites in bile after one week of exposure indicated that these PAHs were bioavailable and taken up, metabolised and excreted to bile by the fish in all exposed groups. The range of concentrations of 1OH-pyrene in bile was lower but close to concentrations observed in soles caught following the "Erika" oil spill (Budzinski et al., 2004). During the experiment, fish were fed twice a week thus bile was regularly evacuated to the intestines. After three weeks of exposure, most $\mathrm{PAH}$ metabolite concentrations in bile were reduced to within the range of PAH metabolite concentrations in control group fish and corresponded well with the observed temporal reductions in water PAH concentrations. PAH metabolite concentrations in bile may therefore indicate short term exposure, but depending on feeding status of the fish metabolite concentrations also have the potential to remain elevated for weeks following exposure to PAHs or dispersed oil (Aas et al., 2000a, 2000b).

The dose-related increase in hepatic CYP1A mRNA in all treatments at both time points indicated that the WAFs from ALC, NSC and diesel contained AhR agonists that activated CYP1A gene transcription (Goksøyr and Förlin, 1992). The 
associated temporal reductions of $\mathrm{PAH}$ concentrations in water demonstrated that hepatic CYP1A gene expression in Atlantic cod, in addition to being a sensitive biomarker, could be expected to last for weeks following an oil exposure incident. Whether this was a result of a continued DNA transcription, high mRNA stability, low rate of mRNA degradation or other species-specific factors is not known, but a rapid CYP1A mRNA turnover (days) has been indicated in other fish species following intraperitoneal injections of CYP1A inducers (Durieux et al., 2012; Kloepper-Sams and Stegeman, 1989; Nahrgang et al., 2009). An extended period (four weeks) of CYP1A mRNA induction was however also observed in polar cod (Boreogadus saida) following exposure to WAF from a NSC oil (Nahrgang et al., 2010).

The effects on CYP1A protein were however not as clear. Hepatic CYP1A protein was induced after three weeks in some of the treatments (ALC and diesel), but with large variability among individuals (table 5; figure 3B). Such a lag between CYP1A mRNA transcription and protein expression was expected and has also been observed in other fish species (e.g. Durieux et al., 2012; Nahrgang et al., 2009). The large variability within groups in CYP1A protein expression could be due to individual differences in response times and sensitivity to potential agonists or inhibitors. Binding affinity of PAHs to the teleost AhR may predict the potency for CYP1A protein induction (Billiard et al., 2002), thus for single compound exposures a good correlation between CYP1A gene and protein expression would be expected. No compounds are yet known to inhibit the translation of CYP1A mRNA to protein, although fluoranthene may inhibit EROD activity (Willett et al., 2001). Translation and/or degradation of mRNA is regulated by miRNAs, which may be altered by xenobiotics (Jenny et al., 2012; Tsuchiya et al., 2006). 
There was an increase in gill and/or hepatic EROD activity in fish exposed to WAF from ALC and NSC oils, also corresponding to an increase in hepatic CYP1A protein in cod exposed to WAF from ALC for 3 weeks. The trends were less consistent in the same biomarkers in cod exposed to WAF from NSC oil. WAF from diesel did not induce gill or hepatic EROD activity, but did clearly induce CYP1A gene and protein expression after 3 weeks of exposure. The EROD activity was in a similar (liver) and lower (gills) range than EROD activity in cod exposed to $1 \mathrm{ppm}$ North Sea crude oils (Abrahamson et al. 2008; Aas et al., 2000a). The lack of response relationships to $\mathrm{PAH}$ concentration may indicate concentration dependent effects of antagonists on EROD activity or differences in toxicokinetics (Curtis et al., 2011; Sturve et al., 2006; Viarengo et al., 1997; Willett et al., 2001). The dose-related effect on hepatic CYP1A gene expression in all treatments, as well as the induction of CYP1A protein and lack of EROD induction in liver in cod exposed to diesel WAF, suggests the former to be the more probable scenario. The ratios between low $(<=4$ rings) and high (>4-rings) molecular weight PAH metabolites in bile were higher in the cod exposed to the diesel than to the NSC and ALC WAFs. Some low molecular weight PAHs and metals have been shown to inhibit EROD activity (Pathiratne and Hemachandra, 2010; Willett et al., 2001; Whyte et al., 2000). It is also possible that endocrine disruptors in oil produce crosstalk between the estrogen and aryl hydrocarbon receptors that could inhibit in vivo EROD activity in liver (Kirby et al., 2007). Only low vitellogenin concentrations in a few individuals were observed in the current study indicating a low potential for estrogen receptor activation. The higher ratio of saturates to aromatic compounds in the diesel and NSC oils may have modulated (inhibited) EROD activity in cod exposed to these oil WAFs. 
The activity of the phase II glutathione S-transferase (GST) isozymes in gills was not affected by the oil WAF treatments, indicating that the WAFs were poor GST inducers in Atlantic cod or that the GST enzymatic conjugating capacity was already sufficient (tables 4 and 5; figure 4). In fish, other phase II enzymes such as glucuronosyltransferases and sulfotransferases may also contribute significantly to, or dominate the conjugating capacity but substrate selectivity may vary (Celander et al., 1993; Van Der Oost et al., 2003; Willett et al., 2000). Although some GSTs may be induced through AhR activation (George, 1994), it has been shown that GSTs are not as easily inducible as the phase I system and that exposure to PCDDs and PAHs may cause both induction and inhibition of GST activities (for summary see Van Der Oost et al., 2003). A lack of GST induction or insufficient GST conjugating capacity could increase the residence time for electrophiles in the liver; a risk factor for chemical carcinogenesis in cod compared to other species with an easily inducible GST system such as starry flounder (Platichthys stellatus) or sea bass (Dicentrarchus labrax) (Kerambrun et al., 2012; Varanasi et al., 1987).

WAF from diesel appeared to have a larger potential than oil WAFs for producing oxidative damage in gills (TBARS). Although differences between crude oil and diesel exposure were moderate, the highest fold-change values of TBARS in gills were observed in cod exposed to WAF from diesel after both one and three weeks of exposure (figure 4). A low potential of North Sea crude oil for producing oxidative damage in liver was previously observed in Atlantic cod following exposure to $0.5 \mathrm{ppm}$ North Sea oil for 15 days (Sturve et al., 2006). The increase over time in TBARS concentration in cod exposed to the lower diesel WAF concentration may indicate that the higher diesel WAF exposure activated lipid metabolism and thus regeneration mechanisms more efficiently than the lower diesel WAF exposure. An 
oxidation of polyunsaturated fatty acids may induce regulatory feedback mechanisms on the expression of lipid metabolism genes (Sampath and Ntambi, 2005), thus increasing their rate of anabolism. Effects of a mixture of PAHs on the expression of key genes related to lipid metabolism (e.g. upregulation of fasn and cebpa) and oxidative stress (e.g. in iron metabolism) have previously been demonstrated in zebrafish (Danio rerio) and Atlantic cod (Holth et al., 2008, 2010). Multivariate analyses indicated that TBARS and gill EROD were the two biomarkers discriminating best between the oil types after one week of exposure (Holth et al., 2012).

Lipid peroxidation, generally thought to be a consequence of oxidative stress (Kappus, 1987), may also be linked to perturbations such as decreased lysosomal membrane stability, carcinogenesis and micronuclei formation (Brinkmann et al., 2013; Köhler et al., 2002). The lack of differences in frequency of fish with micronuclei present/absent among treatments may indicate a low potential, especially of crude oil WAFs, to produce chromosomal aberrations on the implemented timescale in cod erythrocytes (table S8). The micronuclei frequencies in individuals exposed to diesel WAF for three weeks were clearly higher than the suggested micronucleus background assessment criteria (Davies et al., 2012). There might also be both species and tissue differences in susceptibility for micronuclei formation, and although peripheral blood cells are the most commonly used cell type they may be less responsive than e.g. cephalic kidney cells or hepatocytes (Baršienė et al., 2006; Pietrapiana et al., 2002; Rybakovas et al., 2009; Viarengo et al., 2007). This may be a result of a relatively long erythrocyte turnover rate, estimated to extend 100 days in some fish species (Soldatov, 2005). Increasing the interval from exposure to sampling may therefore also improve sensitivity for detecting damage in erythrocytes, but at the 
same time complicate the exposure scenario, especially in wild collected fish. Erythrocyte micronuclei formation appear to be a relevant biomarker following longterm exposure, especially to diesel type oil spills, but assessing other tissues may improve sensitivity and reduce the latency period also for other oil types.

Acetylcholine esterase activity (AChE) in cod muscle was not affected by exposure to the oil or diesel WAFs. WAFs from other oils and wastewater from oil production facilities may however contain compounds capable of inhibiting fish AChE both in vitro and in vivo (Casini et al., 2006; Holth and Tollefsen, 2012; Vieira et al., 2008). In the current experiment, a reduction of AChE activity in muscle was observed in cod from some of the treatments (including the control group), when compared to cod from the pre-exposure control group. Such a reduction in AChE activity could be a response to a reduced swimming activity or confinement stress (as suggested in e.g. Payne et al., 1996), and demonstrates the value of including preexposure controls. The range of enzymatic activities was similar to or even slightly higher than AChE activity measured in muscle from cod collected in the Baltic Sea (Schnell et al., 2008).

There was a low potency for vitellogenin protein induction of the NSC, ALC and diesel oil WAFs. After one week, vitellogenin concentrations in plasma were below the assay detection limit $\left(93 \mathrm{ng} \mathrm{mL}^{-1}\right)$ in most of the cod. After three weeks most of the cod exposed to WAF from $6 \mathrm{~g} \mathrm{~kg}^{-1}$ gravel of NSC, ALC or diesel had plasma vitellogenin concentrations above $93 \mathrm{ng} \mathrm{mL}^{-1}$ and up to $670 \mathrm{ng} \mathrm{mL}^{-1}$, even though PAH concentrations were reduced to background levels during the time-course of the experiment. Four weeks of exposure to $0.5 \%$ produced water from Ekofisk did not induce vitellogenin synthesis in juvenile cod (Sundt et al., 2012), but juvenile cod exposed to $1 \%$ produced water from Oseberg $\mathrm{C}$ for 78 days still had induced 
vitellogenin concentrations in plasma following two months of recovery in natural seawater (Meier et al., 2010). The in vitro estrogen receptor agonist potency has been shown to vary significantly between oil fields (Thomas et al., 2004a, 2004b). Considering the huge potential for vitellogenin synthesis in juvenile cod (in the mg $\mathrm{mL}^{-1}$ plasma range) (Meier et al., 2010), the concentrations measured in the current study were considered close to background. Possibly, a longer exposure period would have produced higher vitellogenin concentrations and more differentiated results between oil types.

Some of the responses changed significantly in the control group over the duration of the experiment. It is unlikely that this was due to solvent in the gravel, which would have evaporated, but reflect changes from the fish adapted to the tanks. In our view, tank controls are the most appropriate for comparing with exposures, but such changes over time suggest a need for further investigation of the time required for adaptation and the extent to which the exposure in itself affects responses.

\section{Conclusions}

Juvenile Atlantic cod were exposed for one and three weeks to two environmentally realistic concentrations of water-accommodated fractions from Arabian Light crude oil, North Sea crude oil and ship-diesel. PAH metabolites measured in cod bile confirmed that oil components were bioavailable and metabolised by the fish. There were clear differences in responses in the CYP1A pathway between oil types: exposure to WAF from ALC oil clearly induced EROD activity in gills and liver. Responses in EROD activity of exposure to WAF from NSC were less clear, and there was no induction of EROD activity after exposure to WAF from diesel. This could be due to interactions from other components in oil and may lead to 
underestimation of the potential for EROD induction. The gene expression of CYP1A in liver was a sensitive biomarker for all tested oil types, and the expression was maintained for three weeks although concentrations of PAHs in water and their metabolites in bile were reduced to background. A time lag between CYP1A mRNA and protein expression was observed in some of the treatments (ALC, diesel), but the extent of CYP1A protein expression was variable between treatments and individuals. In contrast, WAF from diesel appeared to have higher potential for inducing lipid peroxidation (TBARS) in gills and micronuclei in erythrocytes than crude oil WAFs. GST activity, vitellogenin synthesis and AChE activity did not appear to be modulated by any of the treatments.

\section{Acknowledgements}

This work was performed at the Biological Station Drøbak (University of Oslo) in Drøbak, Norway. Assistance from students at the University of Oslo during fish sampling, and technical contribution of Joana Almeida, Luís Luís and Dr. Luís Vieira (AChE/GST determinations) were greatly appreciated. This work was financially supported by: the RCN - Research Council of Norway, Norway; Defra - Department for Environment and Rural Affairs, UK; the French National Agency of Research ANR; MICINN - Ministry of Science and Innovation, Spain; and the Portuguese Foundation for the Science and Technology of Portugal (FCT: ERAAMPERA/0001/2007), through the project European concerted action to foster prevention and best response to Accidental marine Pollution - AMPERA (ERACCT2005- 016165) within the framework of the EU ERA-Net initiative $\left(6^{\text {th }}\right.$ Framework Program). 


\section{References}

Aas, E., Baussant, T., Balk, L., Liewenborg, B., Andersen, O.K., 2000a. PAH metabolites in bile, cytochrome P4501A and DNA adducts as environmental risk parameters for chronic oil exposure: a laboratory experiment with Atlantic cod. Aquat. Toxicol. 51, 241-258.

Aas, E., Beyer, J., Goksøyr, A., 2000b. Fixed wavelength fluorescence (FF) of bile as a monitoring tool for polyaromatic hydrocarbon exposure in fish: an evaluation of compound specificity, inner filter effect and signal interpretation. Biomarkers 5, 923.

Abrahamson, A., Brandt, I., Brunstrom, B., Sundt, R.C., Jorgensen, E.H., 2008. Monitoring contaminants from oil production at sea by measuring gill EROD activity in Atlantic cod (Gadus morhua). Environ. Pollut. 153, 169-175.

Almeida, J.R., Gravato, C., Guilhermino, L., 2012. Challenges in assessing the toxic effects of polycyclic aromatic hydrocarbons to marine organisms: A case study on the acute toxicity of pyrene to the European seabass (Dicentrarchus labrax L.). Chemosphere 86, 926-937.

Amat, A., Burgeot, T., Castegnaro, M., Pfohl-Leszkowicz, A., 2006. DNA adducts in fish following an oil spill exposure. Environ. Chem. Lett. 4, 93-99.

Barron, M.G., Carls, M.G., Short, J.W., Rice, S.D., 2003. Photoenhanced toxicity of aqueous phase and chemically dispersed weathered Alaska North Slope crude oil to Pacific herring eggs and larvae. Environ. Toxicol. Chem. 22, 650-660.

Baršienė, J., Dedonyte, V., Rybakovas, A., Andreikènaitė, L., Andersen, O.K., 2006. Investigation of micronuclei and other nuclear abnormalities in peripheral blood and kidney of marine fish treated with crude oil. Aquat. Toxicol. 78, S99-S104. 
Baršienè, J., Lyons, B.P., Rybakovas, A., Martínez-Gómez, C., Andreikenaite, L., Brooks, S., Maes, T., 2012. Background document: micronucleus assay as a tool for assessing cytogenic/DNA damage in marine organisms, in: Davies, I.M., Vethaak, A.D. (Eds.), Integrated marine environmental monitoring of chemicals and their effects. ICES Cooperative Research Report No. 315. 277 pp.

Billiard, S.M., Hahn, M.E., Franks, D.G., Peterson, R.E., Bols, N.C., Hodson, P.V., 2002. Binding of polycyclic aromatic hydrocarbons (PAHs) to teleost aryl hydrocarbon receptors (AHRs). Comp. Biochem. Physiol. B-Biochem. Mol. Biol. $133,55-68$.

Bird, R.P., Draper, H.H., 1984. Comparative studies on different methods of malonaldehyde determination. Methods Enzymol. 105, 299-305.

Bolognesi, C., Hayashi, M., 2011. Micronucleus assay in aquatic animals. Mutagenesis 26, 205-213.

Bradford, M.M., 1976. Rapid and sensitive method for quantification of microgram quantities of protein utilizing principle of protein-dye binding. Anal. Biochem. 72, $248-254$

Brinkmann, M., Hudjetz, S., Kammann, U., Hennig, M., Kuckelkorn, J., Chinoraks, M., Cofalla, C., Wiseman, S., Giesy, J.P., Schäffer, A., Hecker, M., Wölz, J., Schüttrumpf, H., Hollert, H., 2013. How flood events affect rainbow trout: Evidence of a biomarker cascade in rainbow trout after exposure to $\mathrm{PAH}$ contaminated sediment suspensions. Aquat. Toxicol. 128-129, 13-24.

Budzinski, H., Mazéas, O., Tronczynski, J., Désaunay, Y., Bocquené, G., Claireaux, G., 2004. Link between exposure of fish (Solea solea) to PAHs and metabolites: Application to the "Erika" oil spill. Aquat. Living Resour. 17, 329-334. 
Burgeot, T., Bocquene, G., Porte, C., Dimeet, J., Santella, R.M., 1996. Bioindicators of pollutant exposure in the northwestern Mediterranean sea. Mar. Ecol. Prog. Ser. $131,125-141$

Burke, M.D., Mayer, R.T., 1974. Ethoxyresorufin - direct fluorimetric assay of a microsomal O-dealkylation which is preferentially inducible by 3methylcholanthrene. Drug Metab. Dispos. 2, 583-588.

Carls, M.G., Rice, S.D., Hose, J.E., 1999. Sensitivity of fish embryos to weathered crude oil: Part I. Low-level exposure during incubation causes malformations, genetic damage, and mortality in larval Pacific herring (Clupea pallasi). Environ. Toxicol. Chem. 18, 481-493.

Casini, S., Marsili, L., Fossi, M.C., Mori, G., Bucalossi, D., Porcelloni, S., Caliani, I., Stefanini, G., Ferraro, M., di Catenaja, C.A., 2006. Use of biomarkers to investigate toxicological effects of produced water treated with conventional and innovative methods. Mar. Environ. Res. 62, S347-S351.

Celander, M., Leaver, M.J., George, S.G., Förlin, L., 1993. Induction of cytochrome P450 1A1 and conjugating enzymes in rainbow trout (Oncorhynchus mykiss) liver: A time course study. Comp. Biochem. Physiol. C 106, 343-349.

Claireaux, G., Désaunay, Y., Akcha, F., Aupérin, B., Bocquené, G., Budzinski, F.N., Cravedi, J.P., Davoodi, F., Galois, R., Gilliers, C., Goanvec, C., Guérault, D., Imbert, N., Mazéas, O., Nonnotte, G., Nonnotte, L., Prunet, P., Sébert, P., Vettier, A., 2004. Influence of oil exposure on the physiology and ecology of the common sole Solea solea: Experimental and field approaches. Aquat. Living Resour. 17, $335-351$.

Conover, W.J., 1999. Practical nonparametric statistics, 3rd ed. Wiley, New York. 
Costa, L.G., 2006. Current issues in organophosphate toxicology. Clin. Chim. Acta $366,1-13$.

Curtis, L.R., Garzon, C.B., Arkoosh, M., Collier, T., Myers, M.S., Buzitis, J., Hahn, M.E., 2011. Reduced cytochrome P4501A activity and recovery from oxidative stress during subchronic benzo[a]pyrene and benzo[e]pyrene treatment of rainbow trout. Toxicol. Appl. Pharmacol. 254, 1-7.

Davies, I.M., Gubbins, M., Hylland, K., Thain, J., Maes, T., Martínez-Gómez, C., Giltrap, M., Burgeot, T., Wosniok, W., Lang, T., Vethaak, D. 2012. Technical annex: assessment criteria for biological effects measurements. In: Davies, I. M. and Vethaak, A. D. (eds). 2012. Integrated marine environmental monitoring of chemicals and their effects. ICES Cooperative Research Report No. 315. 277 pp.

De Perre, C., Le Ménach, K., Ibalot, F., Parlanti, E., Budzinski, H., 2014. Development of solid-phase microextraction to study dissolved organic matterPolycyclic aromatic hydrocarbon interactions in aquatic environment. Anal. Chim. Acta 807, 51-60.

Dévier, M., Le Dû-Lacoste, M., Akcha, F., Morin, B., Peluhet, L., Le Menach, K., Burgeot, T., Budzinski, H., 2013. Biliary PAH metabolites, EROD activity and DNA damage in dab (Limanda limanda) from Seine Estuary (France). Environ. Sci. Pollut. Res. 20, 708-722.

Durieux, E.D.H., Connon, R.E., Werner, I., D'Abronzo, L.S., Fitzgerald, P.S., Spearow, J.L., Ostrach, D.J., 2012. Cytochrome P4501A mRNA and protein induction in striped bass (Morone saxatilis). Fish Physiol. Biochem. 38, 11071116. 
Ellman, G.L., Courtney, K.D., Andres, V.J., Featherstone, R.M., 1961. A new and rapid colorimetric determination of acetylcholinesterase activity. Biochem. Pharmacol. 7, 88-95.

Elordui-Zapatarietxe, S., Rosell-Melé, A., Moraleda, N., Tolosa, I., Albaigés, J., 2010. Phase distribution of hydrocarbons in the water column after a pelagic deep ocean oil spill. Mar. Pollut. Bull. 60, 1667-1673.

Frasco, M.F., Guilhermino, L., 2002. Effects of dimethoate and beta-naphthoflavone on selected biomarkers of Poecilia reticulata. Fish Physiol. Biochem. 26, 149-156.

Fulton, M.H., Key, P.B., 2001. Acetylcholinesterase inhibition in estuarine fish and invertebrates as an indicator of organophosphorus insecticide exposure and effects. Environ. Toxicol. Chem. 20, 37-45.

Galgani, F., Bocquene, G., 1991. Semiautomated colorimetric and enzymatic assays for aquatic organisms using microplate readers. Water res. 25, 147-150.

George, S.G., 1994. Enzymology and molecular biology of phase II xenobioticconjugating enzymes in fish, in: Malins, D.C., Ostrander, G.K. (Eds.), Aquatic toxicology; Molecular, Biochemical and Cellular perspectives. Lewis Publishers, Boca Raton, pp. 37-85.

Goksøyr, A., Förlin, L., 1992. The cytochrome-P450 system in fish, aquatic toxicology and environmental monitoring. Aquat. Toxicol. 22, 287-311.

González, J.J., Viñas, L., Franco, M.A., Fumega, J., Soriano, J.A., Grueiro, G., Muniategui, S., López-Mahía, P., Prada, D., Bayona, J.M., Alzaga, R., Albaigés, J., 2006. Spatial and temporal distribution of dissolved/dispersed aromatic hydrocarbons in seawater in the area affected by the Prestige oil spill. Mar. Pollut. Bull. 53, 250-259. 
Guilhermino, L.c., Lopes, M.C., Carvalho, A.P., Soared, A.M.V.M., 1996. Inhibition of acetylcholinesterase activity as effect criterion in acute tests with juvenile Daphnia Magna. Chemosphere 32, 727-738.

Habig, W.H., Jakoby, W.B., 1981. Assays for differentiation of glutathione STransferases. Methods Enzymol. 77, 398-405.

Harman, C., Thomas, K., Tollefsen, K.E., Meier, S., Bøyum, O., Grung, M., 2009. Monitoring the freely dissolved concentrations of polycyclic aromatic hydrocarbons (PAH) and alkylphenols (AP) around a Norwegian oil platform by holistic passive sampling. Mar. Pollut. Bull. 58, 1671-1679.

Harvey, J.S., Lyons, B.P., Page, T.S., Stewart, C., Parry, J.M., 1999. An assessment of the genotoxic impact of the Sea Empress oil spill by the measurement of DNA adduct levels in selected invertebrate and vertebrate species. Mutat. Res.-Gen. Tox. En. 441, 103-114.

Hermes-Lima, M., Willmore, W.G., Storey, K.B., 1995. Quantification of lipid peroxidation in tissue extracts based on Fe(III)xylenol orange complex formation. Free Radic. Biol. Med. 19, 271-280.

Hodson, P.V., Qureshi, K., Noble, C.A.J., Akhtar, P., Brown, R.S., 2007. Inhibition of CYP1A enzymes by alpha-naphthoflavone causes both synergism and antagonism of retene toxicity to rainbow trout (Oncorhynchus mykiss). Aquat. Toxicol. 81, $275-285$

Holth, T.F., Eidsvoll, D.P., Farmen, E., Martínez-Gómez, C., Budzinski, H., Burgeot, T., Guilhermino, L., Hylland, K., 2012. Toxicological profiling of water-soluble fractions of crude oil and diesel in Atlantic cod (Gadus morhua). Proceedings of the $35^{\text {th }}$ AMOP Technical Seminar on Environmental Contamination and Response. Vancouver, Canada, 5 June through 7 june, pp. 37-48. 
Holth, T.F., Nourizadeh-Lillabadi, R., Blæsbjerg, M., Grung, M., Holbech, H., Petersen, G.I., Aleström, P., Hylland, K., 2008. Differential gene expression and biomarkers in zebrafish (Danio rerio) following exposure to produced water components. Aquat. Toxicol. 90, 277-291.

Holth, T.F., Thorsen, A., Olsvik, P.A., Hylland, K., 2010. Long-term exposure of Atlantic Cod (Gadus morhua) to components of produced water: condition, gonad maturation and gene expression. Can. J. Fish. Aquat. Sci. 67, 1685-1698.

Holth, T.F., Tollefsen, K.E., 2012. Acetylcholine esterase inhibitors in effluents from oil production platforms in the North Sea. Aquat. Toxicol. 112-113, 92-98.

Incardona, J.P., Vines, C.A., Linbo, T.L., Myers, M.S., Sloan, C.A., Anulacion, B.F., Boyd, D., Collier, T.C., Morgan, S., Cherr, G.N., Scholz, N.L., 2012. Potent phototoxicity of marine bunker oil to translucent herring embryos after prolonged weathering. Plos One 7(2):e30116. DOI: 10.1371/journal.pone.0030116.

Jaylet, A., Deparis, P., Ferrier, V., Grinfeld, S., Siboulet, R., 1986. A new micronucleus test using peripheral blood erythrocytes of the newt Pleurodeles waltl to detect mutagens in fresh-water pollution. Mutat. Res. 164, 245-257.

Jenny, M.J., Aluru, N., Hahn, M.E., 2012. Effects of short-term exposure to 2,3,7,8tetrachlorodibenzo-p-dioxin on microRNA expression in zebrafish embryos. Toxicol. Appl. Pharmacol. 264, 262-273.

Jewett, S.C., Dean, T.A., Woodin, B.R., Hoberg, M.K., Stegeman, J.J., 2002. Exposure to hydrocarbons 10 years after the Exxon Valdez oil spill: evidence from cytochrome P4501A expression and biliary FACs in nearshore demersal fishes. Mar. Environ. Res. 54, 21-48. 
Jönsson, M., Abrahamson, A., Brunström, B., Brandt, I., Ingebrigtsen, K., Jørgensen, E.H., 2003. EROD activity in gill filaments of anadromous and marine fish as a biomarker of dioxin-like pollutants. Comp. Biochem. Physiol. C 136, 235-243.

Jönsson, E.M., Brandt, I., Brunström, B., 2002. Gill filament-based EROD assay for monitoring waterborne dioxin-like pollutants in fish. Environ. Sci. Technol. 36, $3340-3344$

Kappus, H., 1987. Oxidative stress in chemical toxicity. Arch. Toxicol. 60, 144-149.

Kavanagh, R.J., Frank, R.A., Burnison, B.K., Young, R.F., Fedorak, P.M., Solomon, K.R., Van Der Kraak, G., 2012. Fathead minnow (Pimephales promelas) reproduction is impaired when exposed to a naphthenic acid extract. Aquat. Toxicol. 116, 34-42.

Kerambrun, E., Le Floch, S., Sanchez, W., Guyon, H.T., Meziane, T., Henry, F., Amara, R., 2012. Responses of juvenile sea bass, Dicentrarchus labrax, exposed to acute concentrations of crude oil, as assessed by molecular and physiological biomarkers. Chemosphere 87, 692-702.

Kirby, M.F., Neall, P., Tylor, T., 1999. EROD activity measured in flatfish from the area of the Sea Empress oil spill. Chemosphere 38, 2929-2949.

Kirby, M.F., Smith, A.J., Rooke, J., Neall, P., Scott, A.P., Katsiadaki, I., 2007. Ethoxyresorufin-O-deethylase (EROD) and vitellogenin (VTG) in flounder (Platichthys flesus): System interaction, crosstalk and implications for monitoring. Aquat. Toxicol. 81, 233-244.

Kloepper-Sams, P.J., Stegeman, J.J., 1989. The temporal relationships between P450E protein content, catalytic activity, and mRNA levels in the teleost Fundulus heteroclitus following treatment with $\beta$-naphthoflavone. Arch. Biochem. Biophys. $268,525-535$. 
Köhler, A., Wahl, E., Söffker, K., 2002. Functional and morphological changes of lysosomes as prognostic biomarkers of toxic liver injury in a marine flatfish (Platichthys flesus (L.)). Environ. Toxicol. Chem. 21, 2434-2444.

Le Dû-Lacoste, M., 2008. Etude des phénomènes de biotransformation des hydrocarbures aromatiques polycycliques (HAP) par les organismes aquatiques (poissons) : relation exposition-génotoxicité. PhD thesis, ISM-LPTC, Université de Bordeaux 1, Bordeaux, France. http://www.theses.fr/2008BOR13929.

Lee, R.F., Anderson, J.W., 2005. Significance of cytochrome P450 system responses and levels of bile fluorescent aromatic compounds in marine wildlife following oil spills. Mar. Pollut. Bull. 50, 705-723.

Marigómez, I., Soto, M., Cancio, I., Orbea, A., Garmendia, L., Cajaraville, M.P., 2006. Cell and tissue biomarkers in mussel, and histopathology in hake and anchovy from Bay of Biscay after the Prestige oil spill (Monitoring Campaign 2003). Mar. Pollut. Bull. 53, 287-304.

Martínez-Gómez, C., Fernández, B., Valdés, J., Campillo, J.A., Benedicto, J., Sánchez, F., Vethaak, A.D., 2009. Evaluation of three-year monitoring with biomarkers in fish following the Prestige oil spill (N Spain). Chemosphere 74, 613 620.

Martínez-Gómez, C., Lamoree, M., Hamers, T., van Velzen, M., Kamstra, J.H., Fernández, B., Benedicto, J., León, V.M., Vethaak, A.D. 2013. Integrated chemical and biological analysis to explain estrogenic potency in bile extracts of red mullet (Mullus barbatus). Aquat. Toxicol. 134-135, 1-10.

Martínez-Gómez, C., Vethaak, A.D., Hylland, K., Burgeot, T., Köhler, A., Lyons, B.P., Thain, J., Gubbins, M.J., Davies, I.M., 2010. A guide to toxicity assessment 
and monitoring effects at lower levels of biological organization following marine oil spills in European waters. ICES J. Mar. Sci. 67, 1105-1118.

Mazéas, O., Budzinski, H., 2005. Solid-phase extraction and purification for the quantification of polycyclic aromatic hydrocarbon metabolites in fish bile. Anal. Bioanal. Chem. 383, 985-990.

Meier, S., Andersen, T.E., Norberg, B., Thorsen, A., Taranger, G.L., Kjesbu, O.S., Dale, R., Morton, H.C., Klungsøyr, J., Svardal, A., 2007. Effects of alkylphenols on the reproductive system of Atlantic cod (Gadus morhua). Aquat. Toxicol. 81, 207-218.

Meier, S., Morton, H.C., Nyhammer, G., Grøsvik, B.E., Makhotin, V., Geffen, A., Boitsov, S., Kvestad, K.A., Bohne-Kjersem, A., Goksøyr, A., Folkvord, A., Klungsøyr, J., Svardal, A., 2010. Development of Atlantic cod (Gadus morhua) exposed to produced water during early life stages: Effects on embryos, larvae, and juvenile fish. Mar. Environ. Res. 70, 383-394.

Monson, D.H., Doak, D.F., Ballachey, B.E., Bodkin, J.L., 2011. Could residual oil from the Exxon Valdez spill create a long-term population "sink" for sea otters in Alaska? Ecol. Appl. 21, 2917-2932.

Myers, M.S., Johnson, L.L., Collier, T.K., 2003. Establishing the causal relationship between polycyclic aromatic hydrocarbon (PAH) exposure and hepatic neoplasms and neoplasia-related liver lesions in English sole (Pleuronectes vetulus). Hum. Ecol. Risk Assess. 9, 67-94.

Nahrgang, J., Camus, L., Carls, M.G., Gonzalez, P., Jönsson, M., Taban, I.C., Bechmann, R.K., Christiansen, J.S., Hop, H., 2010. Biomarker responses in polar cod (Boreogadus saida) exposed to the water soluble fraction of crude oil. Aquat. Toxicol. 97, 234-242. 
Nahrgang, J., Camus, L., Gonzalez, P., Goksøyr, A., Christiansen, J.S., Hop, H., 2009. PAH biomarker responses in polar cod (Boreogadus saida) exposed to benzo(a)pyrene. Aquat. Toxicol. 94, 309-319.

Neff, J.M., Ostazeski, S., Gardiner, W., Stejskal, I., 2000. Effects of weathering on the toxicity of three offshore australian crude oils and a diesel fuel to marine animals. Environ. Toxicol. Chem. 19, 1809-1821.

Ohkawa, H., Ohishi, N., Yagi, K., 1979. Assay for lipid peroxides in animal tissues by thiobarbituric acid reaction. Anal. Biochem. 95, 351-358.

OSPAR Commision, 2004. OSPAR/ICES Workshop on the evaluation and update of the background reference concentrations (BCRs) and ecotoxicological assessment criteria (EACs) and how these assessment tools should be used in assessing contaminants in water, sediment and biota. OSPAR/ICES Hazardous Substances report No. 214, The Hague, NL: 9-13 February 2004, ISBN 1-904426-52-2.

Pathiratne, A., Hemachandra, C.K., 2010. Modulation of ethoxyresorufin Odeethylase and glutathione S-transferase activities in Nile tilapia (Oreochromis niloticus) by polycyclic aromatic hydrocarbons containing two to four rings: implications in biomonitoring aquatic pollution. Ecotoxicology 19, 1012-1018.

Payne, J.F., Mathieu, A., Melvin, W., Fancey, L.L., 1996. Acetylcholinesterase, an old biomarker with a new future? Field trials in association with two urban rivers and a paper mill in Newfoundland. Mar. Pollut. Bull. 32, 225-231.

Pietrapiana, D., Modena, M., Guidetti, P., Falugi, C., Vacchi, M., 2002. Evaluating the genotoxic damage and hepatic tissue alterations in demersal fish species: a case study in the Ligurian Sea (NW-Mediterranean). Mar. Pollut. Bull. 44, 238-243.

Radović, J.R., Domínguez, C., Diez, S., Readman, J.W., Bayona, J.M., 2012. Compositional properties and environmental conditions controlling the fate of 
commonly transported oils in the marine environment. J. Environ. Monitor. 14, $3220-3229$

Raingeard, D., Bilbao, E., Sáez-Morquecho, C., de Cerio, O.D., Orbea, A., Cancio, I., Cajaraville, M.P., 2009. Cloning and transcription of nuclear receptors and other toxicologically relevant genes, and exposure biomarkers in European hake (Merluccius merluccius) after the Prestige oil spill. Marine Genomics 2, 201-213.

Reddy, C.M., Quinn, J.G., 2001. The North Cape oil spill: hydrocarbons in Rhode Island coastal waters and Point Judith Pond. Mar. Environ. Res. 52, 445-461.

Rees, C.B., McCormick, S.D., Vanden Heuvel, J.P., Li, W.M., 2003. Quantitative PCR analysis of CYP1A induction in Atlantic salmon (Salmo salar). Aquat. Toxicol. 62, 67-78.

Roche, H., Buet, A., Ramade, F., 2002. Accumulation of lipophilic microcontaminants and biochemical responses in eels from the Camargue Biosphere Reserve. Ecotoxicology 11, 155-164.

Rybakovas, A., Baršienè, J., Lang, T., 2009. Environmental genotoxicity and cytotoxicity in the offshore zones of the Baltic and the North seas. Mar. Environ. Res. 68, 246-256.

Sampath, H., Ntambi, J.M., 2005. Polyunsaturated fatty acid regulation of genes of lipid metabolism. Annu. Rev. Nutr. 25, 317-340.

Sauer, T.C., Michel, J., Hayes, M.O., Aurand, D.V., 1998. Hydrocarbon characterization and weathering of oiled intertidal sediments along the Saudi Arabian Coast two years after the Gulf War oil spill. Environ. Int. 24, 43-60.

Schnell, S., Schiedek, D., Schneider, R., Balk, L., Vuorinen, P.J., Karvinen, H., Lang, T., 2008. Biological indications of contaminant exposure in Atlantic cod (Gadus morhua) in the Baltic Sea. Can. J. Fish. Aquat. Sci. 65, 1122-1134. 
Scott, A., Katsiadaki, I., Witthames, P., Hylland, K., Davies, I., McIntosh, A., Thain, J., 2006a. Vitellogenin in the blood plasma of male cod (Gadus morhua): A sign of oestrogenic endocrine disruption in the open sea? Mar. Environ. Res. 61, 149-170.

Scott, A.P., Katsiadaki, I., Thain, J., 2002. Development of an ELISA for cod vitellogenin and application to assessment of oestrogen exposure in caged cod from the BECPELAG (Biological Effects of Contaminants in Pelagic Ecosystems) workshop. ICES CM 2002/X:10.

Scott, A.P., Kristiansen, S.I., Katsiadaki, I., Thain, J., Tollefsen, K.E., Goksøyr, A., Barry, J., 2006b. Assessment of oestrogen exposure in Cod (Gadus morhua) and Saithe (Pollachius virens) in relation to their proximity to an oilfield, in: Hylland, K., Lang, T., Vethaak, D. (Eds.), Biological Effects of Contaminants in Marine Pelagic Ecosystems. SETAC Press, Belgium, pp. 329-339.

Sherry, J., Gamble, A., Hodson, P., Solomon, K., Hock, B., Marx, A., Hansen, P., 1999. Vitellogenin induction in fish as an indicator of exposure to environmental estrogens, in: Rao, S.S. (Ed.), Impact Assessment of Hazardous Aquatic Contaminants. Lewis Publishers, Boca Raton, pp. 123-160.

Smith, E.L., Rowland, S.J., Galloway, T.F., Scarlett, A., Canty, M.N., 2005. Potential ecological effects of chemically dispersed and biodegraded oils. Report No 480, University of Plymouth, Plymouth, p. 52.

Sokal, R.R., Rohlf, F.J., 1994. Biometry: the principles and practice of statistics in biological research, 2nd ed. W.H. Freeman \& Company, New York.

Soldatov, A.A., 2005. Peculiarities of organization and functioning of the fish red blood system. J. Evol. Biochem. Physiol. 41, 272-281.

Stagg, R.M., Rusin, J., McPhail, M.E., McIntosh, A.D., Moffat, C.F., Craft, J.A., 2000. Effects of polycyclic aromatic hydrocarbons on expression of CYP1A in 
salmon (Salmo salar) following experimental exposure and after the Braer oil spill. Environ. Toxicol. Chem. 19, 2797-2805.

Sturve, J., Hasselberg, L., Falth, H., Celander, M., Förlin, L., 2006. Effects of North Sea oil and alkylphenols on biomarker responses in juvenile Atlantic cod (Gadus morhua). Aquat. Toxicol. 78, S73-S78.

Sundt, R.C., Ruus, A., Jonsson, H., Skarphéðinsdóttir, H., Meier, S., Grung, M., Beyer, J., Pampanin, D.M., 2012. Biomarker responses in Atlantic cod (Gadus morhua) exposed to produced water from a North Sea oil field: Laboratory and field assessments. Mar. Pollut. Bull. 64, 144-152.

Thomas, K.V., Balaam, J., Hurst, M.R., Thain, J.E., 2004a. Bio-analytical and chemical characterisation of offshore produced water effluents for estrogen receptor (ER) agonists. J. Environ. Monitor. 6, 593-598.

Thomas, K.V., Balaam, J., Hurst, M.R., Thain, J.E., 2004b. Identification of in vitro estrogen and androgen receptor agonists in North Sea offshore produced water discharges. Environ. Toxicol. Chem. 23, 1156-1163.

Thomas, K.V., Langford, K., Petersen, K., Smith, A.J., Tollefsen, K.E., 2009. Effectdirected identification of naphthenic acids as important in vitro xeno-estrogens and anti-androgens in North Sea offshore produced water discharges. Environ. Sci. Technol. 43, 8066-8071.

Torres, M.A., Testa, C.P., Gáspari, C., Masutti, M.B., Panitz, C.M.N., Curi-Pedrosa, R., de Almeida, E.A., Di Mascio, P., Wilhelm, D., 2002. Oxidative stress in the mussel Mytella guyanensis from polluted mangroves on Santa Catarina Island, Brazil. Mar. Pollut. Bull. 44, 923-932. 
Tsuchiya, Y., Nakajima, M., Takagi, S., Taniya, T., Yokoi, T., 2006. MicroRNA regulates the expression of human cytochrome P450 1B1. Cancer Res. 66, 90909098.

Utvik, T.I.R., 1999. Chemical characterisation of produced water from four offshore oil production platforms in the North Sea. Chemosphere 39, 2593-2606.

Van Der Oost, R., Beyer, J., Vermeulen, N.P.E., 2003. Fish bioaccumulation and biomarkers in environmental risk assessment: a review. Environ. Toxicol. Pharmacol. 13, 57-149.

Varanasi, U., Stein, J.E., Nishimoto, M., Reichert, W.L., Collier, T.K., 1987. Chemical carcinogenesis in feral fish: uptake, activation and detoxication of organic xenobiotics. Environ. Health Perspect. 71, 155-170.

Viarengo, A., Bettella, E., Fabbri, R., Burlando, B., Lafaurie, M., 1997. Heavy metal inhibition of EROD activity in liver microsomes from the bass Dicentrarchus labrax exposed to organic xenobiotics: Role of GSH in the reduction of heavy metal effects. Mar. Environ. Res. 44, 1-11.

Viarengo, A., Dondero, F., Pampanin, D.M., Fabbri, R., Poggi, E., Malizia, M., Bolognesi, C., Perrone, E., Gollo, E., Cossa, G.P., 2007. A biomonitoring study assessing the residual biological effects of pollution caused by the HAVEN wreck on marine organisms in the Ligurian sea (Italy). Arch. Environ. Contam. Toxicol. $53,607-616$

Vieira, L.R., Gravato, C., Soares, A., Morgado, F., Guilhermino, L., 2009. Acute effects of copper and mercury on the estuarine fish Pomatoschistus microps: Linking biomarkers to behaviour. Chemosphere 76, 1416-1427.

Vieira, L.R., Sousa, A., Frasco, M.F., Lima, I., Morgado, L., Guilhermino, L., 2008. Acute effects of benzo[a]pyrene, anthracene and a fuel oil on biomarkers of the 
common goby Pomatoschistus microps (Teleostei, Gobiidae). Sci. Total Environ. $395,87-100$.

Wang, Z., Fingas, M., 1995. Study of the effects of weathering on the chemical composition of a light crude oil using GC/MS GC/FID. J. Microcolumn Sep. 7, 617-639.

Wessel, N., Dû-Lacoste, M.L., Budzinski, H., Burgeot, T., Akcha, F., 2013. UPLC MS/MS Quantification of primary metabolites of benzo[a]pyrene and fluoranthene produced in vitro by sole (Solea solea) liver microsomal activation. Polycycl. Aromat. Comp. 33, 52-71.

Whyte, J.J., Jung, R.E., Schmitt, C.J., Tillitt, D.E., 2000. Ethoxyresorufin-Odeethylase (EROD) activity in fish as a biomarker of chemical exposure. Crit. Rev. Toxicol. 30, 347-570.

Willett, K.L., Gardinali, P.R., Lienesch, L.A., Di Giulio, R.T., 2000. Comparative metabolism and excretion of benzo(a)pyrene in 2 species of ictalurid catfish. Toxicol. Sci. 58, 68-76.

Willett, K.L., Wassenberg, D., Lienesch, L., Reichert, W., Di Giulio, R.T., 2001. In vivo and in vitro inhibition of CYP1A-dependent activity in Fundulus heteroclitus by the polynuclear aromatic hydrocarbon fluoranthene. Toxicol. Appl. Pharmacol. $177,264-271$ 
Table 1

\begin{tabular}{|c|c|c|c|c|c|c|c|}
\hline Treatment & $\begin{array}{c}\text { Dose } \\
\left(\mathrm{g} \mathrm{kg}^{-1} \text { gravel }\right) \\
\end{array}$ & $\begin{array}{l}\text { Weeks of } \\
\text { exposure }\end{array}$ & $\begin{array}{c}\begin{array}{c}\Sigma V O C \\
\left(n g \mathbf{L}^{-1}\right) \mathbf{x}\end{array} \\
\text {, }\end{array}$ & $\begin{array}{l}\mathbf{\Sigma P A H} \\
\left(\mathrm{ng} \mathrm{L}^{-1}\right)\end{array}$ & $\begin{array}{l}\Sigma \mathrm{EC1N} \\
\left(\mathrm{ng} \mathrm{L}^{-1}\right)\end{array}$ & $\begin{array}{c}\Sigma C 2 N \\
\left(n g L^{-1}\right) \\
\end{array}$ & $\begin{array}{l}\Sigma \mathrm{\Sigma C3N} \\
\left(\mathrm{ng} \mathrm{L}^{-1}\right)\end{array}$ \\
\hline \multirow[t]{2}{*}{ Control } & 0 & 1 & $82 \pm 10$ & $5.0 \pm 1.6$ & $13.4 \pm 3.7$ & $23.3 \pm 5.1$ & $21.0 \pm 5.5$ \\
\hline & & 3 & $71 \pm 10$ & $4.9 \pm 1.4$ & $11.7 \pm 2.5$ & $23.8 \pm 2.4$ & $19.9 \pm 2.3$ \\
\hline \multirow[t]{2}{*}{ Arabian Light crude } & 2 & 1 & $320 \pm 228$ & $12.5 \pm 3.1$ & $49.6 \pm 4.1$ & $146.0 \pm 44.5$ & $327.1 \pm 174.6$ \\
\hline & & 3 & $177 \pm 29$ & $6.9 \pm 1.9$ & $18.2 \pm 4.9$ & $25.9 \pm 2.5$ & $23.1 \pm 3.9$ \\
\hline \multirow[t]{2}{*}{ Arabian Light crude } & 6 & 1 & $609 \pm 446$ & $25.5 * \pm 5.2$ & $206.8 * \pm 84.9$ & $669.5^{*} \pm 232.2$ & $1160.0 * \pm 197.4$ \\
\hline & & 3 & $122 \pm 14$ & $8.3 \pm 0.2$ & $17.1 \pm 3.0$ & $26.1 \pm 3.1$ & $26.3 \pm 3.8$ \\
\hline \multirow[t]{2}{*}{ North Sea crude } & 2 & 1 & $527 \pm 432$ & $18.4 * \pm 1.2$ & $42.2 \pm 9.4$ & $96.4 \pm 11.7$ & $170.2 \pm 7.9$ \\
\hline & & 3 & $109 \pm 39$ & $7.1 \pm 1.4$ & $9.9 \pm 2.1$ & $18.6 \pm 3.7$ & $15.0 \pm 0.5$ \\
\hline \multirow[t]{2}{*}{ North Sea crude } & 6 & 1 & $463 \pm 236$ & $97.2 * \pm 16.3$ & $288.5^{*} \pm 112.1$ & $1036.3 * \pm 286.0$ & $1204.7 * \pm 206.9$ \\
\hline & & 3 & $165 \pm 35$ & $11.7 * \pm 1.6$ & $8.4 \pm 1.4$ & $18.7 \pm 2.5$ & $23.8 \pm 2.0$ \\
\hline \multirow[t]{2}{*}{ Diesel } & 2 & 1 & $383 \pm 200$ & $19.0 * \pm 4.0$ & $56.7 \pm 18.5$ & $154.1 \pm 48.3$ & $219.5 \pm 70.0$ \\
\hline & & 3 & $154 \pm 43$ & $6.3 \pm 0.6$ & $10.3 \pm 3.2$ & $18.2 \pm 2.2$ & $20.2 \pm 2.3$ \\
\hline \multirow[t]{2}{*}{ Diesel } & 6 & 1 & $1076 \pm 419$ & $184.9 * \pm 84.6$ & $588.7 \pm 315.9$ & $1986.2 * \pm 1135.7$ & $2166.3 * \pm 1324.6$ \\
\hline & & 3 & $232 * \pm 21$ & $10.1 \pm 1.4$ & $11.9 \pm 1.9$ & $23.4 \pm 0.7$ & $29.9 \pm 1.7$ \\
\hline
\end{tabular}

Table 1 continued

\begin{tabular}{|c|c|c|c|c|c|c|c|c|}
\hline Treatment & $\begin{array}{c}\text { Dose } \\
\left(\mathrm{g} \mathrm{kg}^{-1} \text { gravel }\right) \\
\end{array}$ & $\begin{array}{l}\text { Weeks of } \\
\text { exposure }\end{array}$ & $\begin{array}{l}\Sigma \mathrm{C} 4 \mathbf{N}^{\mathrm{a}} \\
\left(\mathrm{ng} \mathrm{L}^{-1}\right)\end{array}$ & $\begin{array}{c}\Sigma C 1 P^{\mathrm{a}} \\
\left(\operatorname{ng~L}^{-1}\right)\end{array}$ & $\begin{array}{l}\mathbf{E C 2 P ^ { a }} \\
\left(\operatorname{ng~L~L}^{-1}\right)\end{array}$ & $\begin{array}{l}\Sigma C 3 P^{a} \\
\left(n g ~^{-1}\right)\end{array}$ & $\begin{array}{c}\text { DBT }^{\mathrm{a}} \\
\left(\mathrm{ng} \mathrm{L}^{-1}\right)\end{array}$ & $\begin{array}{c}\mathrm{CC1DBT}^{\mathrm{a}} \\
\left(\mathrm{ng} \mathrm{L}^{-1}\right)\end{array}$ \\
\hline Control & 0 & $\begin{array}{l}1 \\
3\end{array}$ & $\begin{array}{c}18.7,33.2, \mathrm{nq} \\
\mathrm{nq}\end{array}$ & $1.5,1.8, \mathrm{nq}$ & $4.7,6.9, \mathrm{nq}$ & $3.4,4.5, \mathrm{nq}$ & $0.8, \mathrm{nq}, \mathrm{nq}$ & $1.2, \mathrm{nq}, \mathrm{nq}$ \\
\hline Arabian Light crude & 2 & 1 & $346.4 \pm 186.3$ & $\begin{array}{l}2.3,3.8, \mathrm{nq} \\
22.7 \pm 11.8\end{array}$ & $\begin{array}{c}\mathrm{nq} \\
39.4 \pm 12.2\end{array}$ & $\begin{array}{c}\mathrm{nq} \\
17.9 \pm 2.2\end{array}$ & $\begin{array}{c}\mathrm{nq} \\
11.9 \pm 5.8\end{array}$ & $\begin{array}{c}\mathrm{nq} \\
74.8 \pm 40.0\end{array}$ \\
\hline & & 3 & $\mathrm{nq}$ & $2.1,3.0, \mathrm{nq}$ & $5.1,6.8, \mathrm{nq}$ & $\mathrm{nq}$ & $0.4,0.3, \mathrm{nq}$ & $0.7,1.4, \mathrm{nq}$ \\
\hline Arabian Light crude & 6 & 1 & $657.7 \pm 40.4$ & $52.5 \pm 7.8$ & $54.6 \pm 13.2$ & $18.8 \pm 2.4$ & $55.5 \pm 13.5$ & $189.6 \pm 24.9$ \\
\hline & & 3 & $14.2, \mathrm{nq}, \mathrm{nq}$ & $2.6, \mathrm{nq}, \mathrm{nq}$ & $5.1,6.2, \mathrm{nq}$ & $\mathrm{nq}$ & $0.3 \pm 0.0$ & $1.4, \mathrm{nq}, \mathrm{nq}$ \\
\hline North Sea crude & 2 & $\begin{array}{l}1 \\
3\end{array}$ & $\begin{array}{c}179.5 \pm 20.3 \\
\mathrm{ng}\end{array}$ & $22.3 \pm 6.5$ & $52.9 \pm 2.2$ & $24.2 \pm 2.2$ & $\begin{array}{c}0.9 \pm 0.1 \\
0.2 . \mathrm{ng} n \mathrm{ng}\end{array}$ & $\begin{array}{c}5.1 \pm 0.6 \\
n q\end{array}$ \\
\hline North Sea crude & 6 & 1 & $\begin{array}{c}542.6 \pm 58.6 \\
17,23, \mathrm{nq}\end{array}$ & $\begin{array}{c}112.7 \pm 19.6 \\
2.0,2.4, \mathrm{nq}\end{array}$ & $\begin{array}{c}107.6 \pm 19.1 \\
7.5 \pm 1.0\end{array}$ & $\begin{array}{l}37.3 \pm 8.5 \\
10.6 \pm 0.8\end{array}$ & $\begin{array}{c}8.5 \pm 1.0 \\
0.3,0.5, \mathrm{nq}\end{array}$ & $\begin{array}{l}23.3 \pm 2.5 \\
1.0, \mathrm{nq}, \mathrm{nq}\end{array}$ \\
\hline Diesel & 2 & 1 & $227.0 \pm 83.1$ & $15.3 \pm 5.0$ & $41.5 \pm 12.0$ & $19.9 \pm 6.3$ & $0.9,0.9, \mathrm{nq}$ & $2.6,3.1, \mathrm{nq}$ \\
\hline Diesel & 6 & $\begin{array}{l}1 \\
3\end{array}$ & $\begin{array}{c}1043.0 \pm 535.8 \\
30.3 \pm 1.2\end{array}$ & $\begin{array}{l}91,219, \mathrm{nq} \\
3.8, \mathrm{nq}, \mathrm{nq}\end{array}$ & $\begin{array}{c}102.6 \pm 29.5 \\
9.3 \pm 1.3\end{array}$ & $\begin{array}{c}0.9,1 \pm 4.7 \\
9.5 \pm 0.4\end{array}$ & $\begin{array}{c}2.0 \pm 0.7 \\
0.5, \mathrm{nq}, \mathrm{nq}\end{array}$ & $\begin{array}{c}4.1 \pm 1.5 \\
\mathrm{nq}\end{array}$ \\
\hline
\end{tabular}

$\mathrm{nq}=$ not quantifiable/below limit of quantification

VOC: volatile organic compounds; C1N: C1-naphthalenes; C2N: C2-naphthalenes; C3N: C3-naphthalenes; C4N: C4-naphthalenes; C1P: C1phenanthrenes; C2P: C2-phenanthrenes; C3P: C3-phenanthrenes; DBT: dibenzothiophene; C1DBT: C1-dibenzothiophenes 
Sum VOC: benzene, toluene, ethylbenzene, xylene, isopropylbenzene, n-propylbenzene, 1,3,5-trimethylbenzene, terbutylbenzene, 1,2,4trimethylbenzene, secbutylbenzene, 4-isopropyltoluene, butylbenzene and naphthalene.

Sum PAH: phenanthrene, anthracene, acenaphthylene, acenaphthene, fluorene, fluoranthene, pyrene, benzo(a)anthracene, chrysene and triphenylene

${ }^{a}$ data not statistically tested 
Table 2

\begin{tabular}{|c|c|c|c|c|c|c|c|c|c|c|c|}
\hline Treatment & $\begin{array}{c}\text { Dose } \\
\left(\mathrm{g} \mathrm{kg}^{-1} \text { gravel) }\right.\end{array}$ & $\begin{array}{l}\text { Weeks of } \\
\text { exposure }\end{array}$ & $\mathbf{n}$ & $\begin{array}{c}\Sigma \mathrm{OOH}- \\
\text { naphthalenes } \\
\left(\mathrm{ng} \mathrm{g}^{-1}\right)\end{array}$ & $\begin{array}{c}\text { 2-OH- } \\
\text { biphenyl } \\
\left(\mathrm{ng} \mathrm{g}^{-1}\right)\end{array}$ & $\begin{array}{c}\Sigma \mathrm{\Sigma OH}- \\
\text { phenanthrenes } \\
\left(\mathrm{ng} \mathrm{g}^{-1}\right)\end{array}$ & $\begin{array}{c}\text { 3-OH- } \\
\text { fluoranthene } \\
\left(\mathrm{ng} \mathrm{g}^{-1}\right)\end{array}$ & $\begin{array}{l}\text { 1-OH- } \\
\text { pyrene } \\
\left(\text { ng g }^{-1}\right)\end{array}$ & $\begin{array}{c}\text { 1-OH- } \\
\text { chrysene } \\
\left(\mathrm{ng} \mathrm{g}^{-1}\right)\end{array}$ & $\begin{array}{c}\Sigma \mathrm{\Sigma OH}- \\
\mathrm{BaP} \\
\left(\mathrm{ng} \mathrm{g}^{-1}\right)\end{array}$ & $\begin{array}{c}\Sigma \mathrm{\Sigma OH}- \\
\text { PAH } \\
\left(\mathrm{ng} \mathrm{g}^{-1}\right)\end{array}$ \\
\hline Pre-exposure control & 0 & 0 & 3 & $4 \pm 0.4$ & $1.4 \pm 0.4$ & $50 \pm 4$ & $32 \pm 2$ & $90 \pm 10$ & $9 \pm 1$ & $29 \pm 8$ & $215 \pm 15$ \\
\hline \multirow[t]{2}{*}{ Control } & 0 & 1 & 3 & $44 \pm 6$ & $8 \pm 5$ & $132 \pm 38$ & $44 \pm 10$ & $112 \pm 32$ & $15 \pm 4$ & $22 \pm 5$ & $377 \pm 89$ \\
\hline & & 3 & 2 & 36,58 & 12,24 & 115,215 & 30,58 & 71,179 & 8,22 & 21,43 & 294,599 \\
\hline \multirow[t]{2}{*}{ Arabian Light crude } & 2 & 1 & 3 & $43 \pm 26$ & $24 \pm 18$ & $232 \pm 61$ & $19, \mathrm{nq}, \mathrm{nq}$ & $346 \pm 77$ & $31 \pm 14$ & $36 \pm 9$ & $720 \pm 159$ \\
\hline & & 3 & 3 & $0.6,0.8, \mathrm{nq}$ & $3.3,9.4, \mathrm{nq}$ & $15 \pm 11$ & $1, \mathrm{nq}, \mathrm{nq}$ & $37 \pm 6$ & $14,21, \mathrm{nq}$ & $23 \pm 6$ & $92 \pm 6$ \\
\hline \multirow[t]{2}{*}{ Arabian Light crude } & 6 & 1 & 2 & 25,48 & 13,60 & 107,291 & $\mathrm{nq}, \mathrm{nq}$ & 204,1041 & 29,32 & 24,96 & 450,1521 \\
\hline & & 3 & 3 & $5 \pm 0.5$ & $20 \pm 8$ & $77 \pm 27$ & $9 \pm 2$ & $79 \pm 24$ & $27 \pm 11$ & $35 \pm 17$ & $252 \pm 66$ \\
\hline \multirow[t]{2}{*}{ North Sea crude } & 2 & 1 & 3 & $39 \pm 3$ & $10 \pm 9$ & $375 \pm 168$ & $7, \mathrm{nq}, \mathrm{nq}$ & $334 \pm 104$ & $46 \pm 10$ & $37 \pm 19$ & $843 \pm 284$ \\
\hline & & 3 & 3 & $6 \pm 0.3$ & $40 \pm 26$ & $31 \pm 7$ & $3, \mathrm{nq}, \mathrm{nq}$ & $124 \pm 28$ & $66 \pm 4$ & $76 \pm 14$ & $345 \pm 17$ \\
\hline \multirow[t]{2}{*}{ North Sea crude } & 6 & 1 & 3 & $116 \pm 48$ & $18 \pm 6$ & $869 \pm 410$ & $27, \mathrm{nq}, \mathrm{nq}$ & $784 \pm 258$ & $90 \pm 20$ & $125 \pm 33$ & $2012 \pm 772$ \\
\hline & & 3 & 3 & $55 \pm 47$ & $31 \pm 11$ & $611 \pm 431$ & $3,16, \mathrm{nq}$ & $190 \pm 71$ & $121 \pm 9$ & $139 \pm 33$ & $1153 \pm 363$ \\
\hline \multirow[t]{2}{*}{ Diesel } & 2 & 1 & 1 & 42 & 1.4 & 1281 & 42 & 840 & 23 & 6 & 2237 \\
\hline & & 3 & 3 & $5 \pm 1$ & $8 \pm 3$ & $137 \pm 34$ & $15 \pm 4$ & $445 \pm 151$ & $20 \pm 6$ & $13 \pm 3$ & $642 \pm 181$ \\
\hline \multirow[t]{2}{*}{ Diesel } & 6 & 1 & 3 & $200 \pm 142$ & $24 \pm 1$ & $1008 \pm 290$ & $29,81, \mathrm{nq}$ & $1021 \pm 182$ & $29 \pm 5$ & $12 \pm 1$ & $2332 \pm 602$ \\
\hline & & 3 & 3 & $9 \pm 2$ & $11 \pm 3$ & $200 \pm 72$ & $6,14, \mathrm{nq}$ & $319 \pm 88$ & $14 \pm 5$ & $25 \pm 7$ & $585 \pm 162$ \\
\hline
\end{tabular}

$\mathrm{nq}=$ not quantifiable/below limit of quantification 
Table 3.

\begin{tabular}{lccc}
\hline Treatment & $\begin{array}{c}\text { Dose } \\
\left(\mathbf{g ~ k g}^{-1} \text { gravel) }\right.\end{array}$ & $\mathbf{n}$ & $\begin{array}{c}\text { Ratio } \\
<\text { 4-ring OH-PAH : } \\
\text { 5-ring OH-PAH } \\
\text { (median, range) }\end{array}$ \\
\hline Arabian Light crude & 2 & 6 & $11(1-26)$ \\
Arabian Light crude & 6 & 5 & $15(4-18)$ \\
North Sea crude & 2 & 6 & $9(3-215)$ \\
North Sea crude & 6 & 6 & $12(2-21)$ \\
Diesel & 2 & 4 & $50^{*}(44-363)$ \\
Diesel & 6 & 6 & $61^{*}(21-240)$ \\
\hline
\end{tabular}


Table 4

\begin{tabular}{|c|c|c|c|c|c|c|c|c|c|}
\hline Treatment & $\begin{array}{c}\begin{array}{c}\text { Dose } \\
\left(\mathrm{g} \mathrm{kg}^{-1} \text { gravel}\right)\end{array} \\
\end{array}$ & $\mathbf{n}$ & $\begin{array}{c}\text { hepatic } \\
\text { CYP1A } \\
\text { mRNA } \\
\text { (normalized } \\
\text { mean) } \\
\end{array}$ & $\begin{array}{c}\text { hepatic } \\
\text { CYP1A } \\
\text { protein } \\
\text { (mOD } \\
\mu \mathrm{g}^{-1} \text { protein) } \\
\end{array}$ & $\begin{array}{c}\text { hepatic } \\
\text { EROD } \\
\text { activity } \\
\text { (pmol min } \\
\text { mg }^{-1} \text { protein) } \\
\end{array}$ & $\begin{array}{c}\text { gill } \\
\text { EROD } \\
\text { activity } \\
\left({\text { fmol } \text { min }^{-1}}^{-1}\right. \\
\left.\text { filament }^{-1}\right) \\
\end{array}$ & $\begin{array}{c}\text { gill } \\
\text { GST } \\
\text { activity } \\
\left(\mu \text { mol min }^{-1}\right. \\
\left.\text { mg }^{-1} \text { protein }\right) \\
\end{array}$ & $\begin{array}{c}\text { gill } \\
\text { LPO } \\
\text { level } \\
\text { (nmol TBARS } \\
\mathbf{g}^{-1} \text { tissue) } \\
\end{array}$ & $\begin{array}{c}\text { muscle } \\
\text { AChE } \\
\text { activity } \\
\text { (nmol min } \\
\text { mg }^{-1} \text { protein) } \\
\end{array}$ \\
\hline Pre-exposure control & 0 & 8 & $887 \pm 130$ & $48 \pm 18$ & $12.1 \pm 2.5$ & $0.3 \pm 0.1$ & $103 \pm 9$ & $127 \pm 12$ & $63 \pm 3$ \\
\hline Control & 0 & 4 & $534 \pm 162$ & $56 \pm 22$ & $3.9 \pm 2.2$ & $1.9^{\dagger} \pm 0.4$ & $67 \pm 11$ & $95 \pm 37$ & $47^{\dagger} \pm 5$ \\
\hline Arabian Light crude & 2 & 3 & $14612 * *+ + \pm 5529$ & $53 \pm 26$ & $12.4 \pm 2.1$ & $3.2^{\dagger} \pm 0.9$ & $70 \pm 21$ & $136 \pm 36$ & $44^{\dagger} \pm 7$ \\
\hline Arabian Light crude & 6 & 4 & $59438^{* *+\dagger} \pm 21016$ & $79 \pm 15$ & $20.0 * \pm 4.1$ & $7.3^{+} \pm 2.2$ & $86 \pm 19$ & $208 \pm 38$ & $45^{\dagger} \pm 6$ \\
\hline North Sea crude & 2 & 4 & $39881 * *+\dagger \pm 9729$ & $82 \pm 5$ & $31.5^{* *+} \pm 7.2$ & $7.8^{*+} \pm 1.1$ & $84 \pm 8$ & $92 \pm 23$ & $58 \pm 3$ \\
\hline North Sea crude & 6 & 4 & $88120^{* *++} \pm 24767$ & $43 \pm 24$ & $19.4 \pm 3.2$ & $7.6^{+} \pm 2.5$ & $79 \pm 16$ & $158 \pm 28$ & $51^{\dagger} \pm 4$ \\
\hline Diesel & 2 & 4 & $5803^{* *+\dagger} \pm 947$ & $49 \pm 12$ & $8.5 \pm 2.8$ & $4.0 \pm 2.6$ & $102 \pm 4$ & $122 \pm 31$ & $56 \pm 6$ \\
\hline Diesel $^{\#}$ & 6 & 2 & 6820,33599 & 7,46 & $1.1,11.5$ & $1.2,6.1$ & 30,73 & 304,393 & 41,50 \\
\hline
\end{tabular}

\#not included in statistical tests $(\mathrm{n}<3)$. Individual values presented. 
Table 5

\begin{tabular}{|c|c|c|c|c|c|c|c|c|c|}
\hline Treatment & $\begin{array}{c}\text { Dose } \\
\left(\mathrm{g} \mathrm{kg}^{-1} \text { gravel) }\right.\end{array}$ & $\mathbf{n}$ & $\begin{array}{c}\text { hepatic } \\
\text { CYP1A } \\
\text { mRNA } \\
\text { (normalized } \\
\text { mean) }\end{array}$ & $\begin{array}{c}\text { hepatic } \\
\text { CYP1A } \\
\text { protein } \\
\text { (mOD } \\
\mu \mathrm{g}^{-1} \text { protein) }\end{array}$ & $\begin{array}{c}\text { hepatic } \\
\text { EROD } \\
\text { activity } \\
\text { (pmol min } \\
\text { mg }^{-1} \text { protein) }\end{array}$ & $\begin{array}{c}\text { gill } \\
\text { EROD } \\
\text { activity } \\
\left(\text { fmol min }^{-1}\right. \\
\left.\text { filament }^{-1}\right)\end{array}$ & $\begin{array}{c}\text { gill } \\
\text { GST } \\
\text { activity } \\
(\mu \text { mol min } \\
\left.\text { mg }^{-1} \text { protein }\right)\end{array}$ & $\begin{array}{c}\text { gill } \\
\text { LPO } \\
\text { level } \\
\text { (nmol TBARS } \\
\mathrm{g}^{-1} \text { tissue) }\end{array}$ & $\begin{array}{c}\text { muscle } \\
\text { AChE } \\
\text { activity } \\
\text { (nmol min } \\
\text { mg }^{-1} \text { protein) }\end{array}$ \\
\hline Control & 0 & 4 & $622 \pm 289$ & $6 \pm 1$ & $9.3 \pm 1.4$ & $0.5 \pm 0.1$ & $67 \pm 16$ & $104 \pm 4$ & $50^{\dagger} \pm 3$ \\
\hline Arabian Light crude & 2 & 3 & $4304 *+ \pm 1679$ & $26 \pm 11$ & $26.4 \pm 7.2$ & $3.1 * \dagger \pm 0.5$ & $88 \pm 9$ & $153 \pm 32$ & $46^{\dagger} \pm 3$ \\
\hline Arabian Light crude & 6 & 4 & $23628^{* *++} \pm 7090$ & $117 * \pm 35$ & $54.8^{* *+} \pm 12.4$ & $4.0^{*+} \pm 1.0$ & $108 \pm 22$ & $200 \pm 39$ & $46^{\dagger} \pm 3$ \\
\hline North Sea crude & 2 & 4 & $24422^{* *++} \pm 4598$ & $62 \pm 26$ & $25.4 \pm 3.9$ & $4.5^{* * \dagger} \pm 0.6$ & $81 \pm 11$ & $181 \pm 32$ & $57 \pm 3$ \\
\hline North Sea crude & 6 & 4 & $34652 * *+\dagger \pm 10398$ & $71 \pm 32$ & $36.5^{*+} \pm 5.5$ & $3.5 * \dagger \pm 0.6$ & $79 \pm 8$ & $103 \pm 9$ & $54 \pm 2$ \\
\hline Diesel & 2 & 4 & $1162 \pm 582$ & $12 \pm 2$ & $11.0 \pm 2.9$ & $1.3 \pm 0.4$ & $67 \pm 14$ & $239 *+ \pm 33$ & $59 \pm 3$ \\
\hline Diesel & 6 & 4 & $9250 * *+\dagger \pm 2939$ & $105^{*} \pm 35$ & $7.7 \pm 2.2$ & $1.3 \pm 0.4$ & $61^{\dagger} \pm 5$ & $134 \pm 30$ & $50 \pm 7$ \\
\hline
\end{tabular}




\section{Table captions}

Table 1. Volatile organic compounds (VOC) and polycyclic aromatic hydrocarbon (PAH) concentrations in water $\left(\mathrm{ng} \mathrm{L}^{-1}\right)$, presented as average \pm standard error when all values were above the quantification limit $(n=3)$. For treatments with at least one value below the quantification limit, individual values are presented. Significant differences to the respective control groups one and three weeks after the start of exposure have been indicated $(p<0.05)$.

Table 2. PAH metabolite concentrations in bile $\left(\mathrm{ng}^{-1}\right)$ presented as average \pm standard error when all values were above the quantification limit ( $n=3$; LOQ). For treatments where $n<3$ or at least one value below $L O Q$, individual values are presented (limit of detection $=0.3 \mathrm{ng} \mathrm{g}^{-1} ; \mathrm{LOQ}=1 \mathrm{ng} \mathrm{g}^{-1}$ ).

Table 3. Relationship (ratio) between $\leq 4$-ring $\mathrm{OH}-\mathrm{PAH}$ and 5-ring $\mathrm{OH}-\mathrm{PAH}$ in cod bile presented as median and min-max (non-parametric statistics applied). Significant differences between groups have been indicated $(*)$.

Table 4. Biomarkers in Atlantic cod from the pre-exposure control group and one week after start of exposure (mean \pm SE). Significant differences to the control group $\left(^{*}\right)$ and the time zero group $\left(^{\dagger}\right)$ have been indicated (one symbol: $p<0.05$; two symbols: $p<0.001)$. 
Table 5. Biomarkers in Atlantic cod three weeks after start of exposure (mean $\pm \mathrm{SE}$ ). Significant differences to the control group $\left(^{*}\right)$ and the time zero group $\left(^{\dagger}\right)$ have been indicated (one symbol: $p<0.05$; two symbols: $p<0.001$ ). 


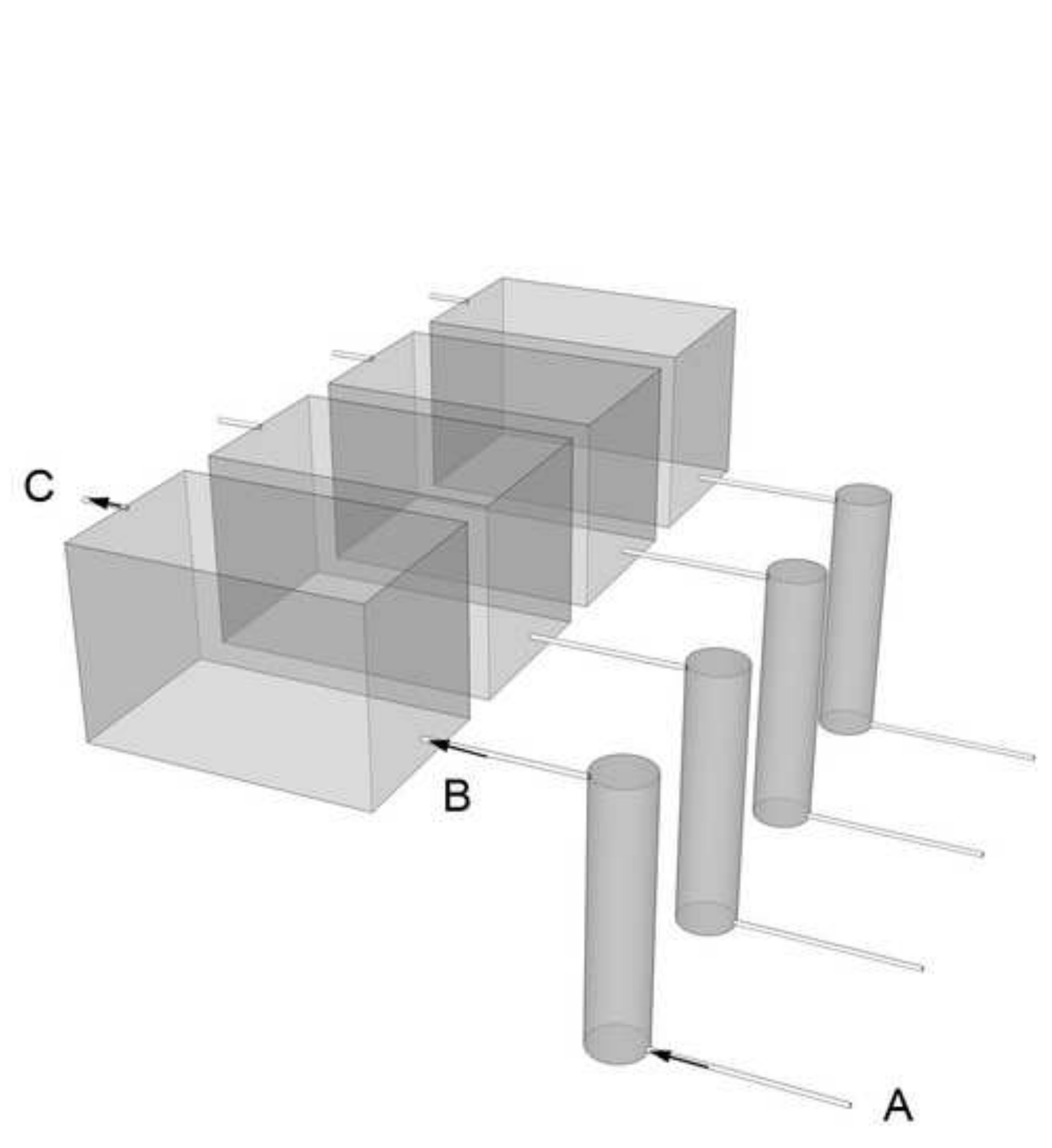

Page 55 of 60

Page 55 of 60

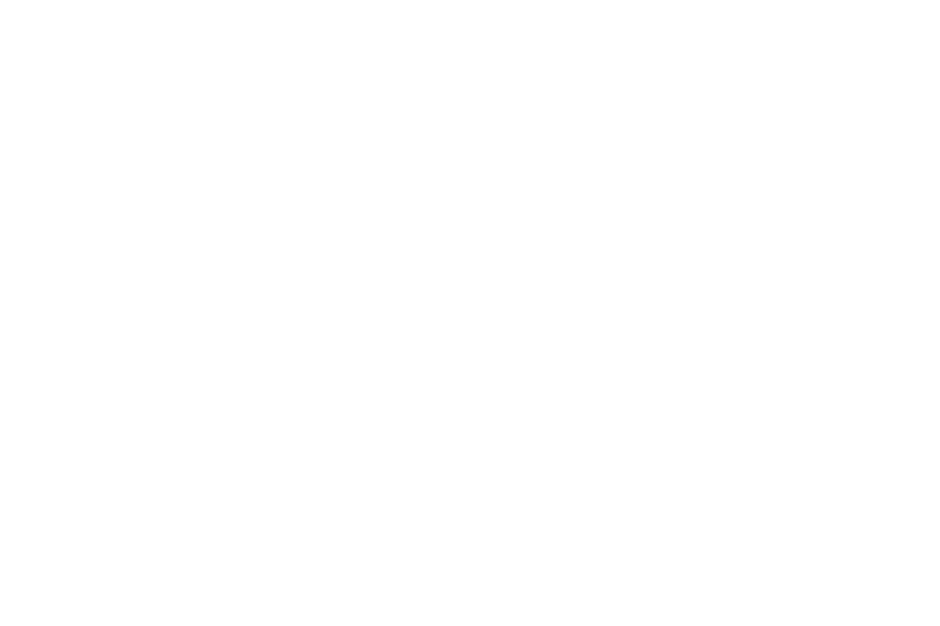




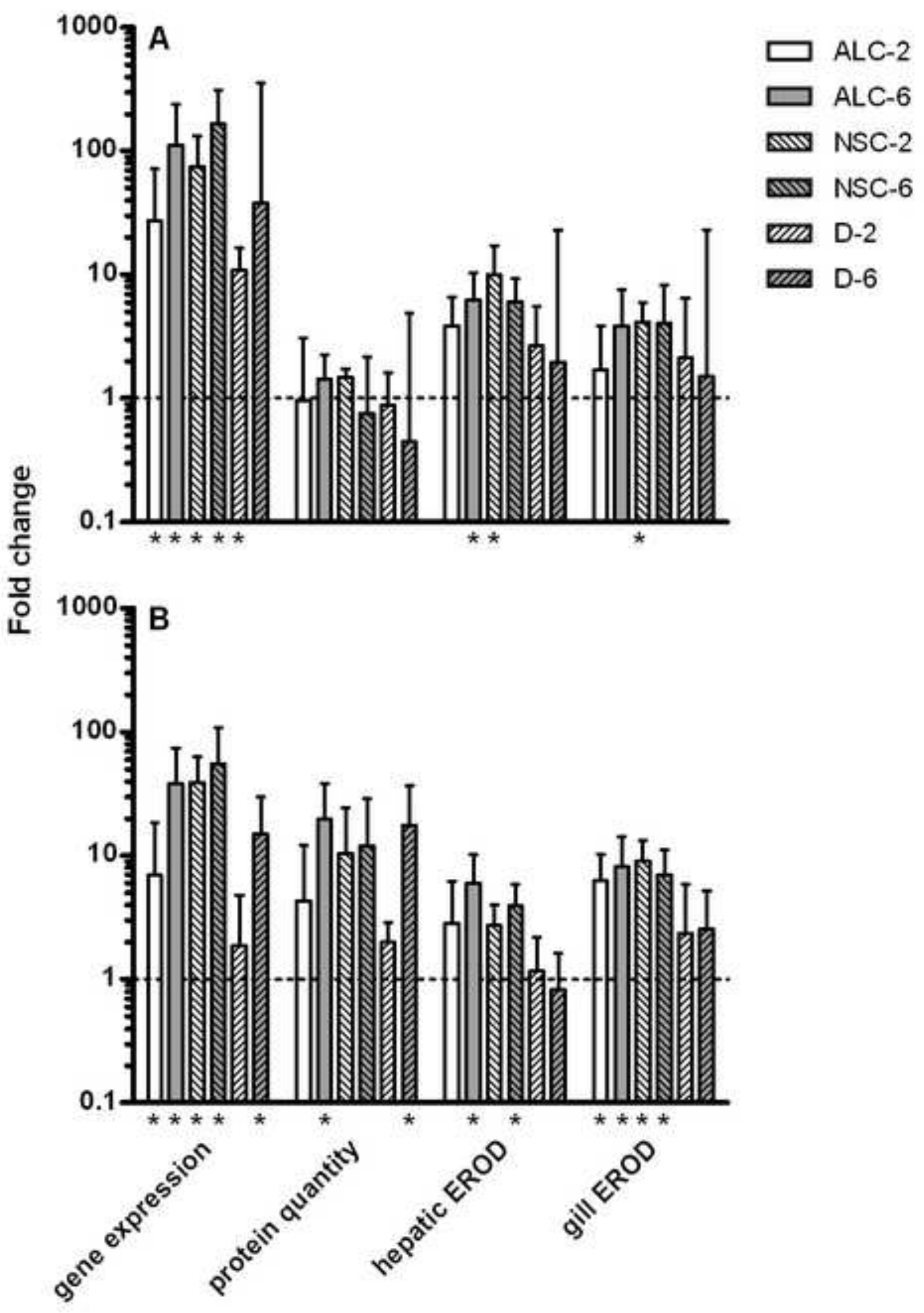



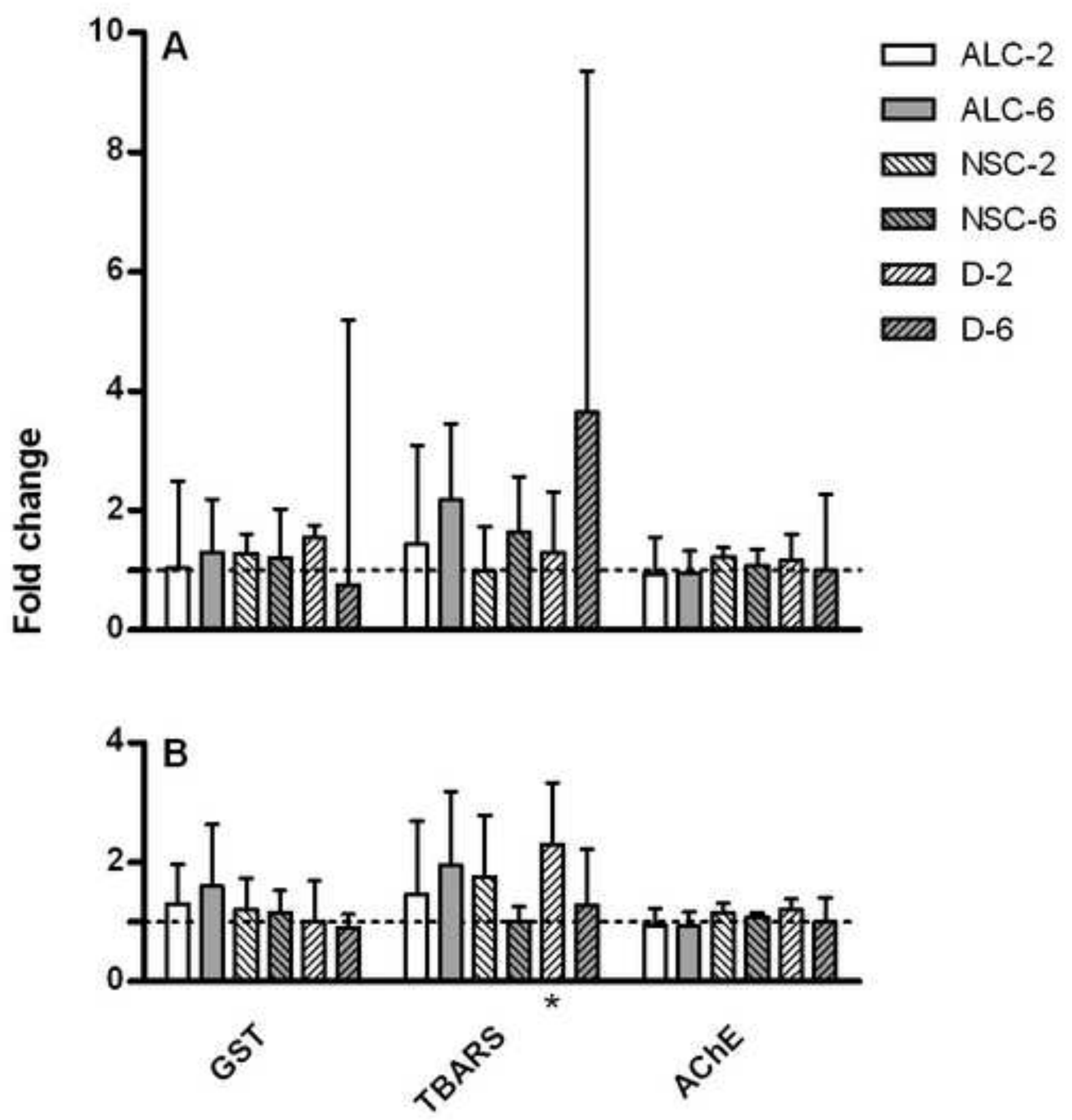
Figure 1. Composition of the three different oils included in the current study. Saturates include iso- and cyclic alkanes. Aromatics include monoaromatics, PAHs and hetero-polycyclic compounds. Resins are heterogeneous compounds, generally of high polarity. Asphaltenes are condensed aromatic macromolecules. Data from Radović et al. (2012).

Figure 2. Experimental setup of one of seven exposure groups: for each treatment, four tanks received effluents from separate columns containing gravel with same oil type and concentration (no oil for the control group). Seawater inlet was at bottom of columns (A), column effluent at top of columns (B), effluent inlet at bottom of aquaria (B) and aquaria outlet at top of aquaria (C). The exposure groups were randomly distributed.

Figure 3. Differences (relative to control) in hepatic CYP1A mRNA, hepatic CYP1A protein, hepatic EROD activity and gill EROD activity in cod after A) one week and B) three weeks of exposure to WAF of 2 and $6 \mathrm{~g} \mathrm{~kg}^{-1}$ gravel of Arabian Light crude oil (ALC), North sea crude oil (NSC) and ship-diesel (D; average and 95\% confidence intervals). Significant differences to the control group have been indicated below X-axis (*; cf tables 3 and 4). Group size (n) as presented in tables 3 and 4.

Figure 4. Differences (relative to control) in gill GST activity, gill LPO level and muscle AChE activity in cod after A) one week and B) three weeks of exposure to WAF of 2 and $6 \mathrm{~g} \mathrm{~kg}^{-1}$ gravel of Arabian Light crude oil (ALC), North sea crude oil (NSC) and ship-diesel (D; average and 95\% confidence intervals). Significant 
differences to the control group have been indicated below x-axis (*; cf tables 3 and 4). Group size (n) as presented in tables 3 and 4. 
- Atlantic cod were exposed to the water-accommodated fraction of three different oils

- PAH metabolites in bile confirmed an environmentally realistic exposure scenario

- Responses in CYP1A and oxidative stress pathways differed among the oil types

- Biomarkers that could differentiate among oil types were recognized 